\title{
Discovery and optimization of small molecule splicing modifiers of survival motor neuron 2 (SMN2) as a treatment for spinal muscular atrophy
}

Matthew G. Woll, Hongyan Qi, Anthony Turpoff, Nanjing Zhang, Xiaoyan Zhang, Guangming Chen, Chunshi Li, Song Huang, Tianle Yang, Young-Choon Moon, ChangSun Lee, Soongyu Choi, Neil G. Almstead, Nikolai A. Naryshkin, Amal Dakka, Jana Narasimhan, Vijayalakshmi Gabbeta, Ellen Welch, Xin Zhao, Nicole Risher, Josephine Sheedy, Marla Weetall, Gary M. Karp*

\section{Contents:}

S2

Supplemental graph 1: Free energy diagram supporting Figure 4 of the manuscript

S3 Supplemental figure 1: Survival, body weight and righting reflex data for compound 20.

S4-S29 Additional synthetic procedures for products and intermediates not fully described in the manuscript.

S30

Supplemental table 1: Primer/probe sequences for the RT qPCR assay described in the manuscript. 
Supplemental Graph 1: The relative energy of the molecules shown in Figure 4 vs. dihedral bond angle (of the highlighted bonds) are plotted. A restricted Hartree-Fock SCF calculation (basis set: $3-21 \mathrm{G}(*)$ ) was performed using Pulay DIIS + Geometric Direct Minimization Optimization on eighty distinct rotational steps from 0 to $360^{\circ}$.

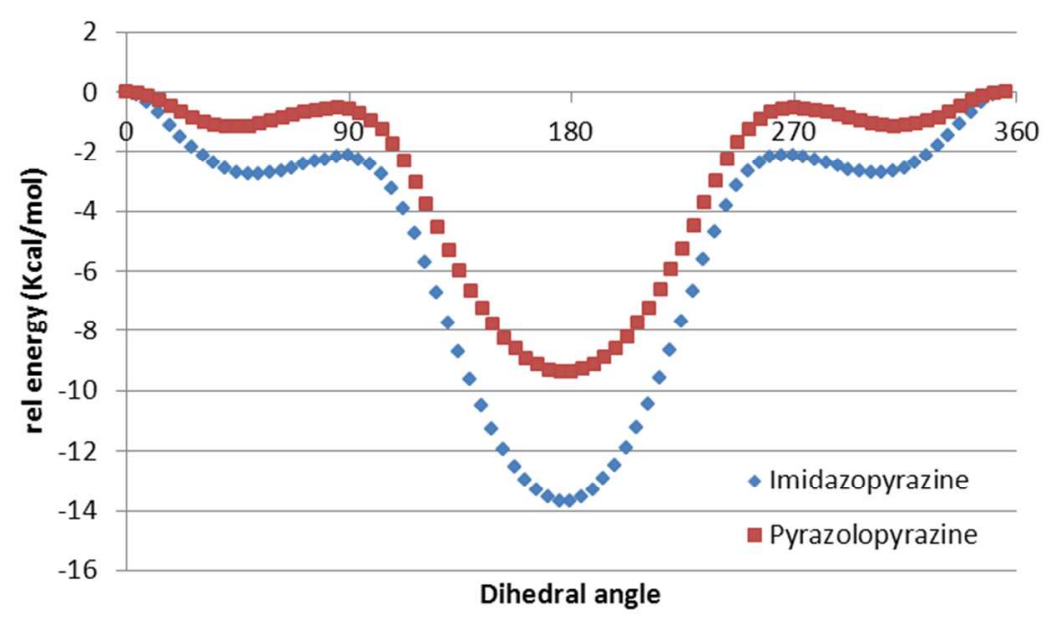


Supplemental Figure 1: Administration of compound 20 increased survival and body weight gain, and improved motor function in SMN $\triangle 7$ SMA mice. Animals were treated with vehicle or 20 at doses of $1 \mathrm{mg} / \mathrm{kg} /$ day or $3 \mathrm{mg} / \mathrm{kg} /$ day from PND3-PND23 by IP injection, and thereafter by oral gavage at doses of $6 \mathrm{mg} / \mathrm{kg} /$ day or $20 \mathrm{mg} / \mathrm{kg} /$ day from PND24 through PND120. Data represent means \pm SEM of an initial group size of 10 (HET), 15 (SMN $\triangle 7$ SMA mice, vehicle dosed), 15 (SMN $\Delta 7 \mathrm{SMA}$ mice, $1 \mathrm{mg} / \mathrm{kg} \mathrm{IP} \rightarrow 6 \mathrm{mg} / \mathrm{kg} \mathrm{PO}$ ), and 11 (SMN $\Delta 7$ SMA mice, 3 $\mathrm{mg} / \mathrm{kg} \mathrm{IP} \rightarrow 20 \mathrm{mg} / \mathrm{kg}$ PO), animals per data point. (A) Kaplan-Meier survival plot. (B) Body weight from PND3-PND100. (C) Latency to righting (in seconds) in neonatal SMN $\triangle 7$ SMA mice. ${ }^{* *} \mathrm{p}<0.01, * * * \mathrm{p}<0.001,{ }^{* * * *} \mathrm{p}<0.0001$ (ANOVA, multiple comparisons vs. vehicledosed SMN $\triangle 7$ SMA)

A.

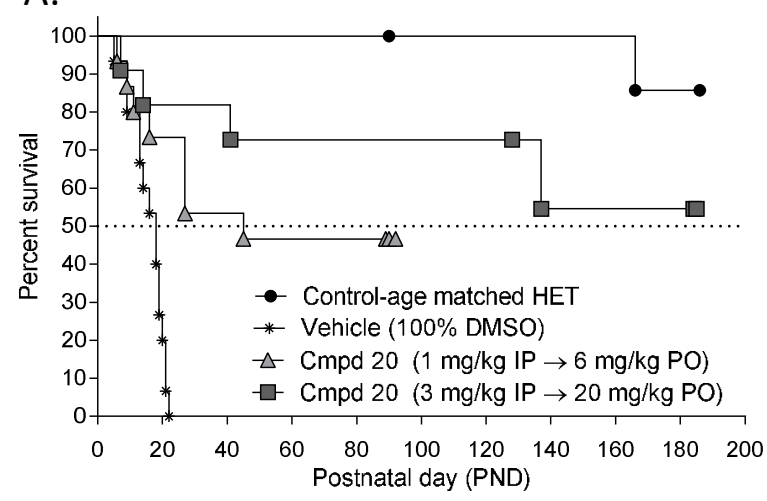

C.

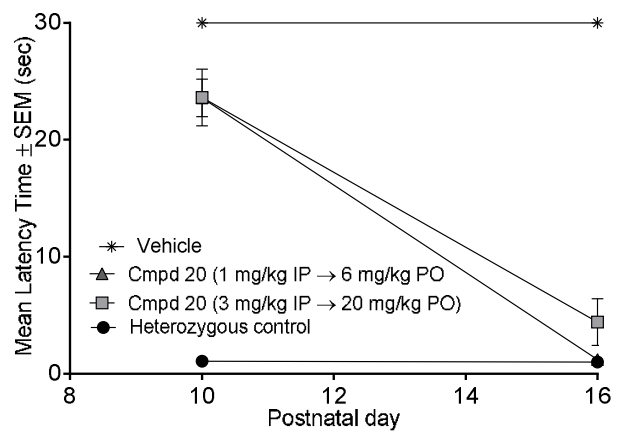

B.

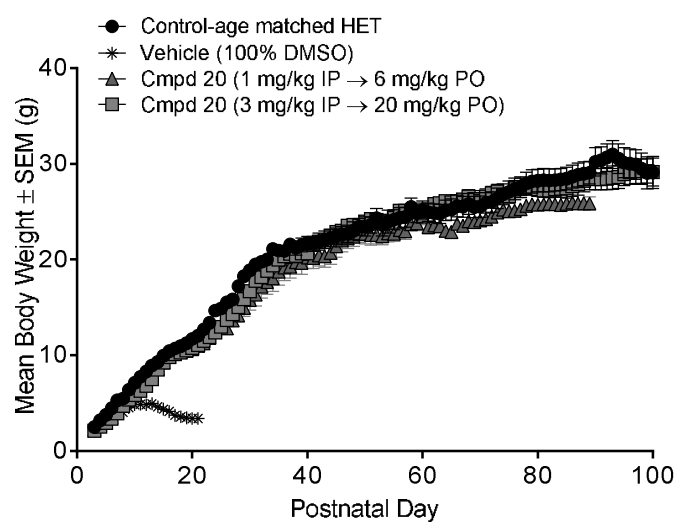

\section{Motor function evaluation of neonatal SMN $\triangle 7$ SMA mice:}

The righting reflex evaluates the time (in seconds) that it takes an animal to right itself when placed on its back. The animal was given a maximum of 30 seconds to complete the test. Ten trials were recorded for each mouse, and the mean of 10 trials/animal was then averaged across the group. 
Scheme 5

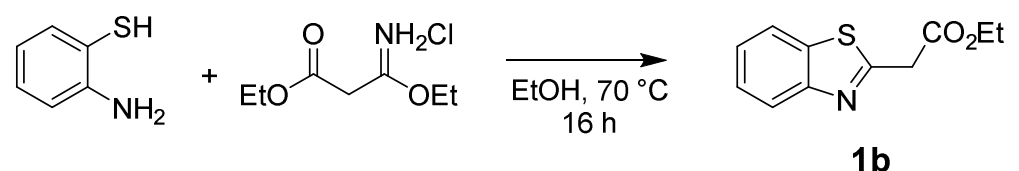

Ethyl 2-(benzo[d]thiazol-2-yl)acetate (1b). A mixture of 2-aminobenzenethiol (6.25 g, 50 $\mathrm{mmol}$ ) and ethyl 3-ethoxy-3-iminopropanoate hydrochloride $(9.75 \mathrm{~g}, 50 \mathrm{mmol})$ in EtOH (50 mL) was stirred at $70{ }^{\circ} \mathrm{C}$ for $16 \mathrm{~h}$. The mixture was partitioned between EtOAc $(200 \mathrm{~mL})$ and $\mathrm{H}_{2} \mathrm{O}$ $(200 \mathrm{~mL})$. The organic layer was washed with brine and concentrated. The residue was chromatographed on silica gel (10\% EtOAc in hexanes) to yield $\mathbf{1 b}(6.0 \mathrm{~g}, 54 \%)$ as a pale yellow oil. ${ }^{1} \mathrm{H}$ NMR $\left(500 \mathrm{MHz}, \mathrm{CDCl}_{3}\right) \delta 8.05(\mathrm{~d}, J=8.2 \mathrm{~Hz}, 1 \mathrm{H}), 7.91(\mathrm{~d}, J=7.9 \mathrm{~Hz}, 1 \mathrm{H}), 7.50(\mathrm{~m}$, $1 \mathrm{H}), 7.43(\mathrm{~m}, 1 \mathrm{H}), 4.28$ (q, $J=7.1 \mathrm{~Hz}, 2 \mathrm{H}), 4.22(\mathrm{~s}, 2 \mathrm{H}), 1.33(\mathrm{t}, J=7.1 \mathrm{~Hz}, 3 \mathrm{H})$.

Scheme 6

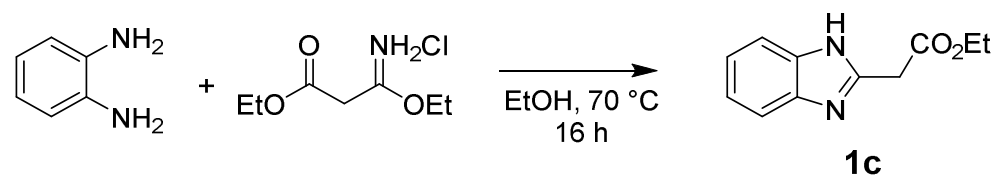

Ethyl 2-(1H-benzo[d]imidazol-2-yl)acetate (1c). A mixture of benzene-1,2-diamine (1.08 $\mathrm{g}, 10 \mathrm{mmol})$ and ethyl 3-ethoxy-3-iminopropanoate hydrochloride $(1.95 \mathrm{~g}, 10 \mathrm{mmol})$ in EtOH $(20 \mathrm{~mL})$ was stirred at $80^{\circ} \mathrm{C}$ for $16 \mathrm{~h}$. The mixture was partitioned between EtOAc $(100 \mathrm{~mL})$ and aqueous saturated $\mathrm{NaHCO}_{3}(100 \mathrm{~mL})$. The organic layer was washed with brine and concentrated. The residue was chromatographed on silica gel $\left(0-10 \% \mathrm{MeOH}\right.$ in $\left.\mathrm{CH}_{2} \mathrm{Cl}_{2}\right)$ to yield $1 \mathrm{c}(1.78 \mathrm{~g}, 87 \%)$ as a tan solid. LC-MS: $m / z=205.2[\mathrm{M}+\mathrm{H}]^{+} ;{ }^{1} \mathrm{H}$ NMR $\left(500 \mathrm{MHz}\right.$, DMSO- $\left.d_{6}\right)$ $\delta 12.36(\mathrm{br} \mathrm{s}, 1 \mathrm{H}), 7.58-7.43(2 \mathrm{H}), 7.18-7.11(2 \mathrm{H}), 4.15(\mathrm{q}, J=6.9 \mathrm{~Hz}, 2 \mathrm{H}), 3.97(\mathrm{~s}, 2 \mathrm{H}), 1.22$ (t, $J=6.9 \mathrm{~Hz}, 3 \mathrm{H})$.

Scheme 7
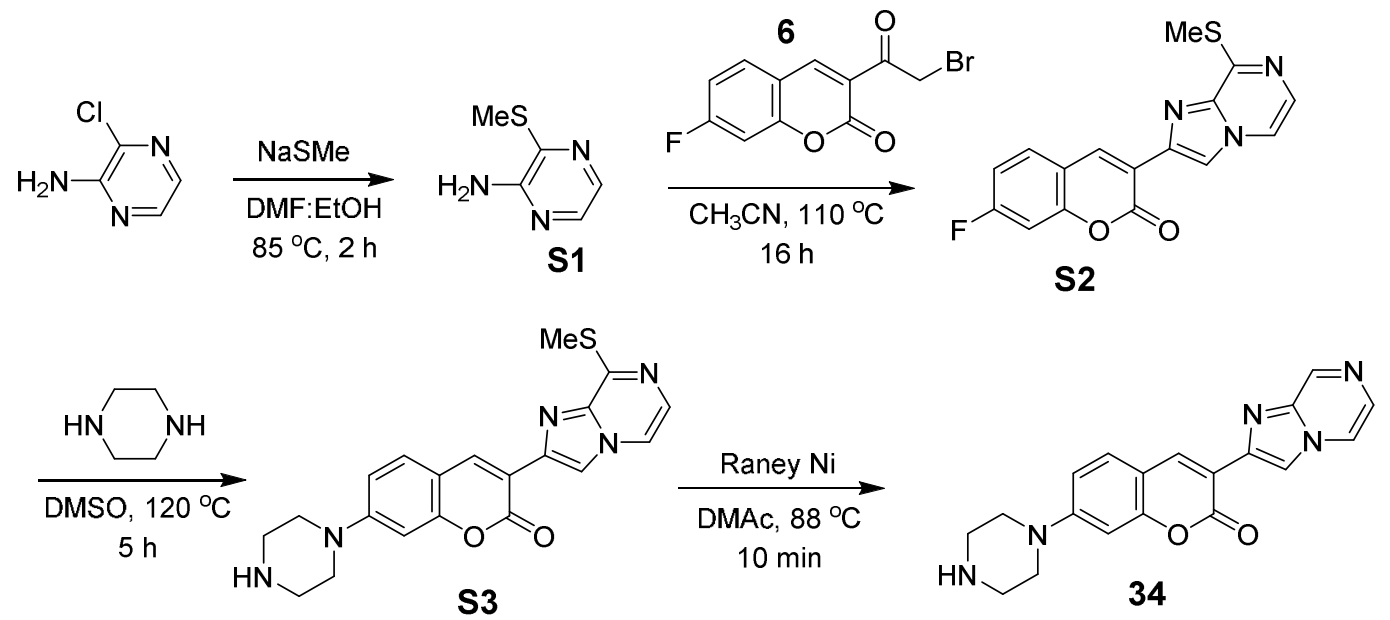
3-(Methylthio)pyrazin-2-amine (S1). A mixture of 3-chloropyrazin-2-amine (1.29 g, 10 $\mathrm{mmol})$ and sodium methanethiolate $(1.05 \mathrm{~g}, 15 \mathrm{mmol})$ in DMF $(10 \mathrm{~mL})$ and $\mathrm{EtOH}(10 \mathrm{~mL})$ was stirred at $85^{\circ} \mathrm{C}$ for $2 \mathrm{~h}$. The mixture was concentrated, diluted with water and filtered. The filtrate was extracted with EtOAc. The organic layer was washed with water, dried over $\mathrm{Na}_{2} \mathrm{SO}_{4}$, filtered and concentrated. The residue was combined with the solid material collected from filtration, affording the desired product $\mathbf{S 1}(1.33 \mathrm{~g}, 94 \%)$ as a white solid. LC-MS: $m / z=142.1$ $[\mathrm{M}+\mathrm{H}]^{+}$.

\section{7-Fluoro-3-(8-(methylthio)imidazo[1,2-a]pyrazin-2-yl)-2H-chromen-2-one} hydrobromide (S2). A mixture of $\mathbf{6}(2.85 \mathrm{~g}, 10 \mathrm{mmol})$ and $\mathbf{S 1}(1.5 \mathrm{~g}, 10 \mathrm{mmol})$ in $\mathrm{CH}_{3} \mathrm{CN}(40$ $\mathrm{mL}$ ) was stirred at $110{ }^{\circ} \mathrm{C}$ overnight. The mixture was cooled to rt and diluted with EtOAc, generating a precipitate. The solid was collected by vacuum filtration, washed with EtOAc and dried, yielding S2 (2.15 g, 66\%) as a tan solid. LC-MS: $m / z=328.1[\mathrm{M}+\mathrm{H}]^{+}$.

\section{7-(4-Piperazin-1-yl)-3-(7-(methylthio)imidazo[1,2-c]pyrimidin-2-yl)-2H-chromen-2- one (S3). A mixture of $\mathbf{S 2}(100 \mathrm{mg}, 0.24 \mathrm{mmol})$ and piperazine (60 $\mathrm{mg}, 0.6 \mathrm{mmol})$ in DMSO $(0.5 \mathrm{~mL})$ was stirred at $120^{\circ} \mathrm{C}$ for $5 \mathrm{~h}$. The mixture was cooled to $\mathrm{rt}$ and diluted with water, generating a precipitate. The solid was collected by vacuum filtration, washed with water, dried and purified with silica gel column chromatography $\left(5-10 \% \mathrm{MeOH}\right.$ in $\mathrm{CH}_{2} \mathrm{Cl}_{2}$ ) to give $\mathbf{S 3}$ (52 $\mathrm{mg}, 55 \%)$ as a yellow solid. LC-MS: $m / z=394.3[\mathrm{M}+\mathrm{H}]^{+} ;{ }^{1} \mathrm{H}$ NMR $\left(500 \mathrm{MHz}, \mathrm{CDCl}_{3}\right) \delta 8.81$ (s, $1 \mathrm{H}), 8.50$ (s, $1 \mathrm{H}), 7.81(\mathrm{~d}, J=4.4 \mathrm{~Hz}, 1 \mathrm{H}), 7.70(\mathrm{~d}, J=4.7 \mathrm{~Hz}, 1 \mathrm{H}), 7.52(\mathrm{~d}, J=8.8 \mathrm{~Hz}, 1 \mathrm{H})$, 6.88 (dd, $J=8.8,2.5 \mathrm{~Hz}, 1 \mathrm{H}), 6.77$ (d, $J=2.2 \mathrm{~Hz}, 1 \mathrm{H}), 3.50$ (s, $1 \mathrm{H}), 3.38-3.30$ (m, 4H), 3.09- $3.01(\mathrm{~m}, 4 \mathrm{H}), 2.71(\mathrm{~s}, 3 \mathrm{H})$.}

\section{3-(Imidazo[1,2-a]pyrazin-2-yl)-7-(piperazin-1-yl)-2H-chromen-2-one (34). Into a} solution of $\mathbf{S 3}(30 \mathrm{mg}, 0.076 \mathrm{mmol})$ in dimethylacetamide $(2.0 \mathrm{~mL})$ at $88^{\circ} \mathrm{C}$ was added a large excess of Raney Ni. The mixture was stirred until gas evolution ceased ( $\sim 10 \mathrm{~min})$. The mixture was diluted with $\mathrm{MeOH}$ and filtered through Celite. The filtrate was concentrated under a stream of nitrogen. The residue was purified by silica gel column chromatography $(5-10 \% \mathrm{MeOH}$ in $\mathrm{CH}_{2} \mathrm{Cl}_{2}$ ) to give 34 (32 mg, $\left.55 \%\right)$ as a yellow solid: $\mathrm{mp} 258-260{ }^{\circ} \mathrm{C}$; LC-MS: $m / z=348.2$ $[\mathrm{M}+\mathrm{H}]^{+} ;{ }^{1} \mathrm{H}$ NMR $\left(500 \mathrm{MHz}, \mathrm{CDCl}_{3}\right) \delta 9.07(\mathrm{~s}, 1 \mathrm{H}), 8.75(\mathrm{~s}, 1 \mathrm{H}), 8.60(\mathrm{~d}, J=0.6 \mathrm{~Hz}, 1 \mathrm{H}), 8.09$ (dd, $J=4.6,1.4 \mathrm{~Hz}, 1 \mathrm{H}), 7.88(\mathrm{~d}, J=4.4 \mathrm{~Hz}, 1 \mathrm{H}), 7.50(\mathrm{~d}, J=8.8 \mathrm{~Hz}, 1 \mathrm{H}), 6.88(\mathrm{dd}, J=8.8,2.2$ $\mathrm{Hz}, 1 \mathrm{H}), 6.78(\mathrm{~d}, J=2.5 \mathrm{~Hz}, 1 \mathrm{H}), 3.36(\mathrm{dd}, J=6.1,4.3 \mathrm{~Hz}, 4 \mathrm{H}), 3.05(\mathrm{dd}, J=6.1,4.3 \mathrm{~Hz}, 4 \mathrm{H})$

Scheme 8 


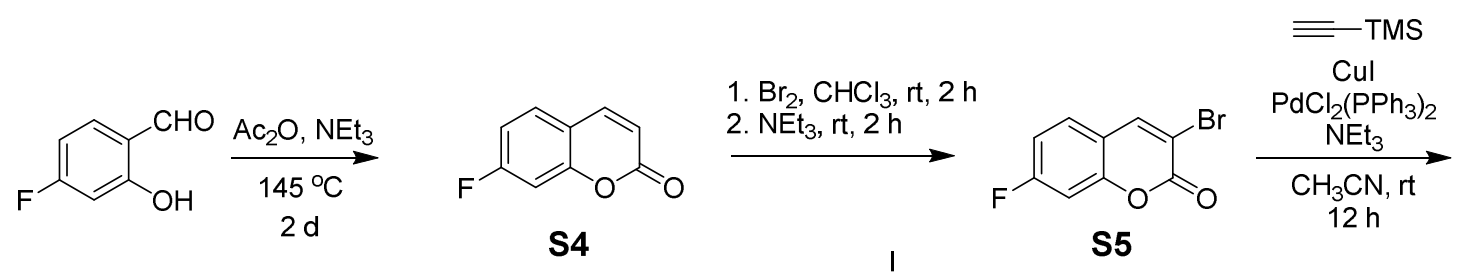

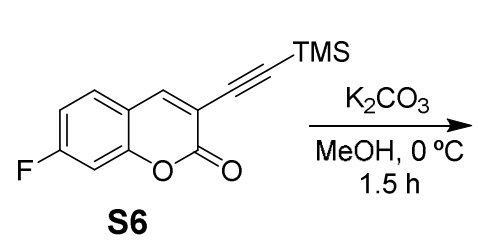

S6

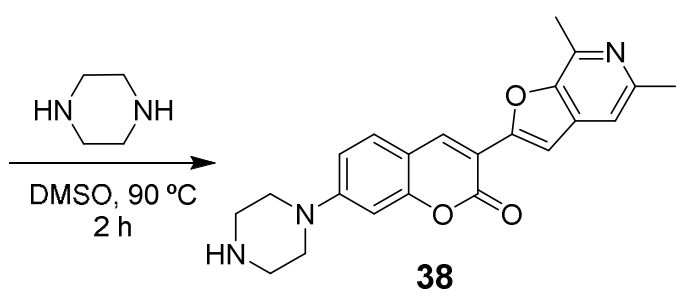

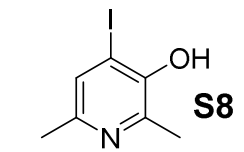

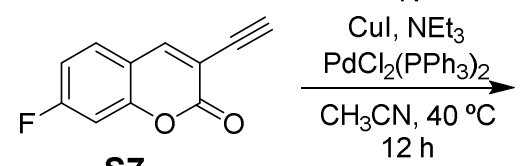

S7

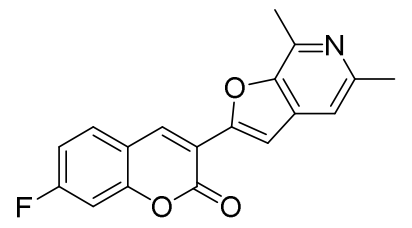

S9

7-Fluorocoumarin (S4). A mixture of 4-fluoro-2-hydroxybenzaldehyde (10 g, $71.4 \mathrm{mmol})$, acetic anhydride $(34 \mathrm{~mL}, 360 \mathrm{mmol})$, and triethylamine $(11 \mathrm{~mL}, 79 \mathrm{mmol})$ was heated at $145^{\circ} \mathrm{C}$ for $2 \mathrm{~d}$. The reaction mixture was then diluted in aqueous $\mathrm{NH}_{4} \mathrm{OH}(500 \mathrm{~mL})$ and filtered. The collected material was dried, yielding $\mathbf{S 4}(10.3 \mathrm{~g}, 88 \%)$ as a brown solid. ${ }^{1} \mathrm{H}$ NMR (500 MHz. $\left.\mathrm{CDCl}_{3}\right) \delta 7.69(\mathrm{~d}, J=9.5 \mathrm{~Hz}, 1 \mathrm{H}), 7.48(\mathrm{dd}, J=8.5,6 \mathrm{~Hz}, 1 \mathrm{H}), 7.07(\mathrm{dd}, J=8.5,2.5 \mathrm{~Hz}, 1 \mathrm{H})$, $7.03(\mathrm{td}, J=8.5,2.5 \mathrm{~Hz}, 1 \mathrm{H}), 6.38(\mathrm{~d}, J=9.5 \mathrm{~Hz}, 1 \mathrm{H})$.

3-Bromo-7-fluoro-2H-chromen-2-one (S5). Bromine (3.81 mL, $74 \mathrm{mmol})$ was added to a stirred solution of $\mathbf{S} 4(3.04 \mathrm{~g}, 18.5 \mathrm{mmol})$ in $\mathrm{CHCl}_{3}(20 \mathrm{~mL})$ at $\mathrm{rt}$. The mixture was stirred at $\mathrm{rt}$ for $2 \mathrm{~h}$, then cooled in an ice-water bath and diluted with $\mathrm{CH}_{2} \mathrm{Cl}_{2}(100 \mathrm{~mL})$. Triethylamine (30.7 $\mathrm{mL}, 222 \mathrm{mmol}$ ) was carefully added. The mixture was stirred at $\mathrm{rt}$ for an additional $2 \mathrm{~h}$. A precipitate formed and was collected by filtration. The solid was washed with $\mathrm{CH}_{2} \mathrm{Cl}_{2}(3 \times 15$ $\mathrm{mL})$. The combined filtrate was concentrated and purified by silica gel column chromatography $\left(\mathrm{CH}_{2} \mathrm{Cl}_{2}\right)$, yielding $\mathbf{S 5}$ (4.07 g, 90\%) as white solid. LC-MS: $m / z=242.4,244.4[\mathrm{M}+\mathrm{H}]^{+} ;{ }^{1} \mathrm{H}$ NMR (500 MHz, $\left.\mathrm{CDCl}_{3}\right) \delta 8.09(\mathrm{~s}, 1 \mathrm{H}), 7.47$ (dd, $\left.J=8.7,5.8 \mathrm{~Hz}, 1 \mathrm{H}\right), 7.12-7.03(\mathrm{~m}, 2 \mathrm{H})$.

7-Fluoro-3-((trimethylsilyl)ethynyl)-2H-chromen-2-one (S6). A mixture of S5 (1.82 g, $7.5 \mathrm{mmol})$, ethynyltrimethylsilane $(0.88 \mathrm{~g}, 9.0 \mathrm{mmol})$, copper(I) iodide $(0.071 \mathrm{~g}, 0.38 \mathrm{mmol})$, bis(triphenylphosphine)palladium(II) dichloride $(0.26 \mathrm{~g}, 0.38 \mathrm{mmol})$, triethylamine $(1.52 \mathrm{~g}, 15.0$ $\mathrm{mmol}$ ) and $\mathrm{CH}_{3} \mathrm{CN}(15 \mathrm{~mL})$ was stirred under an argon atmosphere at $\mathrm{rt}$ for $12 \mathrm{~h}$. Volatiles were removed from the mixture. The residue was purified by silica gel column chromatography (0$50 \%$ EtOAc in hexanes) to give $\mathbf{S 6}(2.08 \mathrm{~g}, 90 \%)$ as white solid. MS $m / z 261.2[\mathrm{M}+\mathrm{H}]^{+}$.

3-Ethynyl-7-fluoro-2H-chromen-2-one (S7). Compound S6 (2.08 g, $8.0 \mathrm{mmol}$ ) was dissolved in $\mathrm{MeOH}(50 \mathrm{~mL})$ and cooled in an ice-water bath. To this solution was added $\mathrm{K}_{2} \mathrm{CO}_{3}$ 
$(1.55 \mathrm{~g}, 11.25 \mathrm{mmol})$. The mixture was stirred at $0{ }^{\circ} \mathrm{C}$ for $1.5 \mathrm{~h}$. Saturated aqueous $\mathrm{NH}_{4} \mathrm{Cl}(200$ $\mathrm{mL}$ ) was added to produce a precipitate. The precipitate was collected, washed with water, dried and purified by silica gel column chromatography $\left(0-10 \%\right.$ EtOAc in $\left.\mathrm{CH}_{2} \mathrm{Cl}_{2}\right)$ to give $\mathbf{S 7}(1.14 \mathrm{~g}$, $76 \%$ ) as white needles. LC-MS: $m / z=189.2[\mathrm{M}+\mathrm{H}]^{+}$.

4-lodo-2,6-dimethylpyridin-3-ol (S8). 2,6-Dimethylpyridin-3-ol (1.0 g, $8.1 \mathrm{mmol})$ was dissolved in aqueous $\mathrm{NaOH}(4.05 \mathrm{~mL}, 2 \mathrm{M}, 8.1 \mathrm{mmol})$. To the solution was added iodine (2.62 $\mathrm{g}, 10.3 \mathrm{mmol}$ ) at rt. The mixture was stirred at $50{ }^{\circ} \mathrm{C}$ for $2 \mathrm{~h}$. The mixture was neutralized ( $\mathrm{pH}$ 7) with aqueous $\mathrm{HCl}(2 \mathrm{~N})$. Excess reagent was quenched with sodium thiosulfate. Volatiles were removed from the mixture. The residue was suspended in $10 \% \mathrm{MeOH}$ in $\mathrm{CH}_{2} \mathrm{Cl}_{2}(100 \mathrm{~mL})$ and filtered. The filtrate was concentrated to give $\mathbf{S 8}(0.96 \mathrm{~g}, 50 \%)$. LC-MS: $m / z=250.0$ $[\mathrm{M}+\mathrm{H}]^{+}$.

3-(5,7-Dimethylfuro[2,3-c]pyridin-2-yl)-7-fluoro-2H-chromen-2-one (S9). A mixture of S8 (343 mg, $1.38 \mathrm{mmol})$, S7 (200 mg, $1.06 \mathrm{mmol}$ ), bis(triphenylphosphine)palladium(II) dichloride (37 mg, $0.05 \mathrm{mmol}$ ), copper(I) iodide (10 $\mathrm{mg}, 0.05 \mathrm{mmol})$, triethylamine $(0.25 \mathrm{~mL}$, $2.12 \mathrm{mmol})$ and DMF $(3.0 \mathrm{~mL})$ was stirred under an argon atmosphere at $40{ }^{\circ} \mathrm{C}$ overnight. The mixture was diluted with water $(50 \mathrm{~mL})$ to produce a precipitate. The precipitate $(185 \mathrm{mg}, 60 \%)$. was collected by filtration. LC-MS: $m / z=311.2[\mathrm{M}+\mathrm{H}]^{+}$.

\section{3-(5,7-Dimethylfuro[2,3-c]pyridin-2-yl)-7-(piperazin-1-yl)-2H-chromen-2-one (38). A} mixture of S9 (100 mg, $0.32 \mathrm{mmol})$, piperazine $(58 \mathrm{mg}, 0.67 \mathrm{mmol})$ and DMSO $(1.0 \mathrm{~mL})$ was stirred at $90^{\circ} \mathrm{C}$ for $2 \mathrm{~h}$. The mixture was cooled to $\mathrm{rt}$ and diluted with water $(10 \mathrm{~mL})$ to produce a precipitate. The precipitate was collected by filtration, washed with water and dried to give $\mathbf{3 8}$ (89 mg, $74 \%$ ) as a yellow powder: $\mathrm{mp} 218-220{ }^{\circ} \mathrm{C}$; $\mathrm{LC}-\mathrm{MS}: \mathrm{m} / \mathrm{z}=376.0 \mathrm{~m} / \mathrm{z}[\mathrm{M}+\mathrm{H}]^{+} ;{ }^{1} \mathrm{H}$ NMR $\left(500 \mathrm{MHz}, \mathrm{CDCl}_{3}\right) \delta 8.36(\mathrm{~s}, 1 \mathrm{H}), 7.56-7.49(\mathrm{~m}, 2 \mathrm{H}), 7.21(\mathrm{~s}, 1 \mathrm{H}), 6.92-6.87(\mathrm{~m}, 1 \mathrm{H}), 6.77-6.74$ (m, 1H), 3.39 (m, $J=10.4 \mathrm{~Hz}, 4 \mathrm{H}), 3.09-3.03(\mathrm{~m}, 4 \mathrm{H}), 2.79(\mathrm{~s}, 3 \mathrm{H}), 2.61$ (s, 3H).

Scheme 9

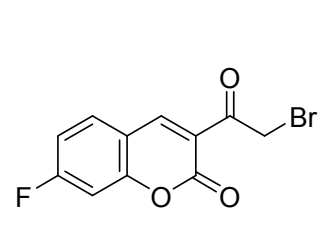

6

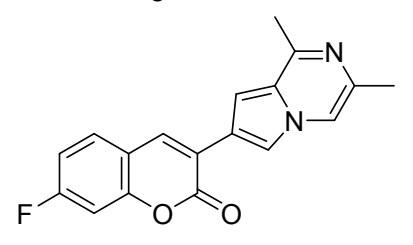

S12

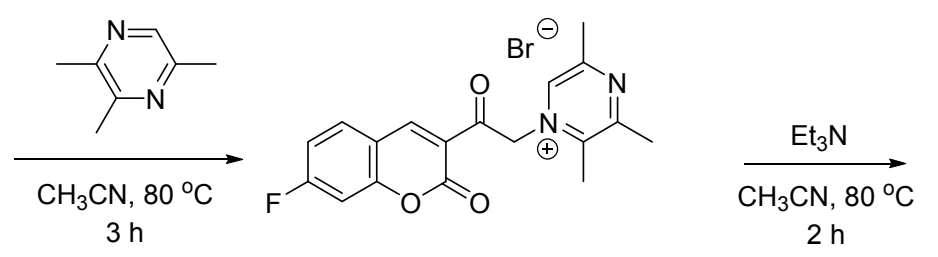

S11
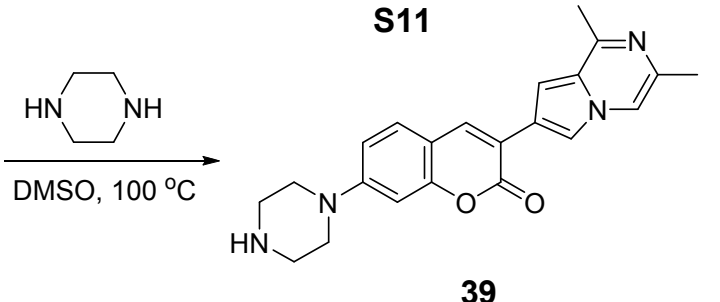

39 


\section{1-(2-(7-Fluoro-2-oxo-2H-chromen-3-yl)-2-oxoethyl)-2,3,5-trimethylpyrazin-1-ium}

bromide (S11). A mixture of 6 (100 $\mathrm{mg}, 0.35 \mathrm{mmol})$ and 2,3,5-trimethylpyrazine ( $86 \mathrm{mg}, 0.70$ mmol) in anhydrous $\mathrm{CH}_{3} \mathrm{CN}(0.5 \mathrm{~mL})$ was heated to $80^{\circ} \mathrm{C}$ for $3 \mathrm{~h}$ in a sealed tube. After cooling to $\mathrm{rt}$, the reaction mixture was stirred at $\mathrm{rt}$ overnight, then filtered. The collected material was washed with a small amount of $\mathrm{CH}_{3} \mathrm{CN}$ to provide crude $\mathbf{S 1 1}(118 \mathrm{mg})$ as a light brown solid, which was used without further purification. LC-MS: $m / z=327.3[\mathrm{M}+\mathrm{H}]^{+}$.

\section{3-(1,3-Dimethylpyrrolo[1,2-a]pyrazin-7-yl)-7-fluoro-2H-chromen-2-one (S12).}

Compound $\mathbf{S 1 1}$ was suspended in $\mathrm{CH}_{3} \mathrm{CN}(2 \mathrm{~mL})$ and triethylamine $(0.5 \mathrm{~mL})$. The mixture was heated to reflux for $2 \mathrm{~h}$, then cooled and filtered. The collected material was washed with a small amount of $\mathrm{CH}_{3} \mathrm{CN}$ to provide $\mathbf{S 1 2}(88 \mathrm{mg}, 82 \%$ over 2 steps) as an orange solid. LC-MS: $\mathrm{m} / \mathrm{z}=$ $309.0[\mathrm{M}+\mathrm{H}]^{+} ;{ }^{1} \mathrm{H}$ NMR $\left(500 \mathrm{MHz}, \mathrm{DMSO}-d_{6}\right) \delta 8.64(\mathrm{~s}, 1 \mathrm{H}), 8.31(\mathrm{~d}, J=1.0 \mathrm{~Hz}, 1 \mathrm{H}), 8.04(\mathrm{~d}$, $J=6.0 \mathrm{~Hz}, 1 \mathrm{H}), 7.83(\mathrm{dd}, J=6.0,2.5 \mathrm{~Hz}, 1 \mathrm{H}), 7.45(\mathrm{dd}, J=9.5,2.0 \mathrm{~Hz}, 1 \mathrm{H}), 7.37(\mathrm{~s}, 1 \mathrm{H}), 7.30$ (dt, $J=9.0,2.5 \mathrm{~Hz}, 1 \mathrm{H}), 2.70(\mathrm{~s}, 3 \mathrm{H}), 2.40(\mathrm{~s}, 3 \mathrm{H})$.

\section{3-(1,3-Dimethylpyrrolo[1,2-a]pyrazin-7-yl)-7-(piperazin-1-yl)-2H-chromen-2-one} (39). A mixture of $\mathbf{S 1 2}(30 \mathrm{mg}, 0.1 \mathrm{mmol})$ and piperazine (17 mg, $0.2 \mathrm{mmol})$ in DMSO (0.3 mL) was heated at $60^{\circ} \mathrm{C}$ for $16 \mathrm{~h}$ in a sealed tube. The mixture was purified by column chromatography on basic alumina $\left(0-10 \% \mathrm{MeOH}\right.$ in $\left.\mathrm{CH}_{2} \mathrm{Cl}_{2}\right)$ to provide $39(13 \mathrm{mg}, 35 \%)$ as a yellow solid: LC-MS: $m / z=375.1[\mathrm{M}+\mathrm{H}]^{+} ;{ }^{1} \mathrm{H}$ NMR $\left(500 \mathrm{MHz}\right.$, DMSO- $\left.d_{6}\right): \delta 8.45(\mathrm{~s}, 1 \mathrm{H})$, $8.25(\mathrm{~d}, J=1.0 \mathrm{~Hz}, 1 \mathrm{H}), 8.01(\mathrm{~s}, 1 \mathrm{H}), 7.58(\mathrm{~d}, J=8.5 \mathrm{~Hz}, 1 \mathrm{H}), 7.31(\mathrm{~s}, 1 \mathrm{H}), 7.05$ (dd, $J=9.0$, $2.5 \mathrm{~Hz}, 1 \mathrm{H}), 6.93(\mathrm{~d}, J=2.5 \mathrm{~Hz}, 1 \mathrm{H}), 3.43$ (br s, 4H), 3.03 (br s, 4H), 2.58 (s, 3H), 2.28 (d, $J=$ $1.0 \mathrm{~Hz}, 3 \mathrm{H})$.

Scheme 10

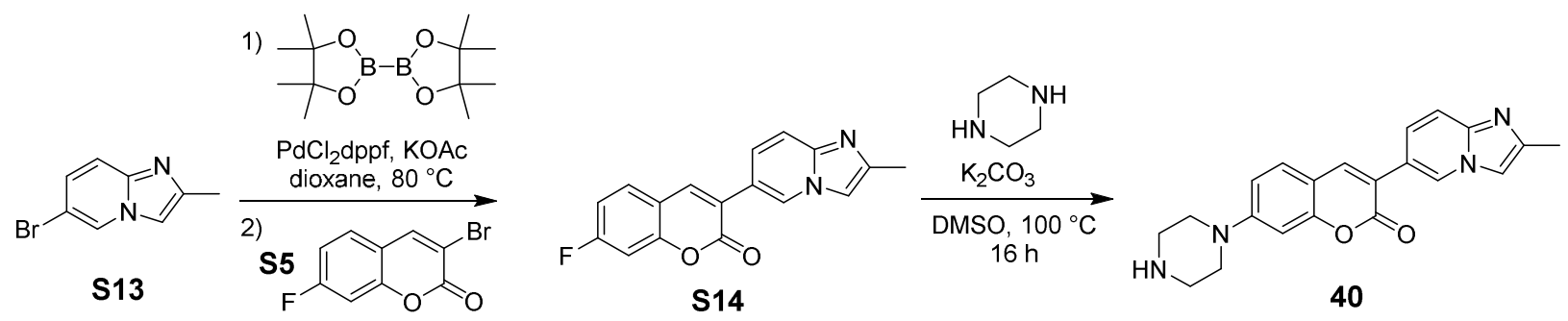

7-Fluoro-3-(2-methylimidazo[1,2-a]pyridin-6-yl)-2H-chromen-2-one (S14). A mixture of $\mathbf{S 1 3}(0.79 \mathrm{~g}, 3.75 \mathrm{mmol}$, prepared according to the procedure for $\mathbf{S 6 3}), 4,4,4^{\prime}, 4^{\prime}, 5,5,5^{\prime}, 5^{\prime}-$ octamethyl-2,2'-bi(1,3,2-dioxaborolane) (1.14 g, $4.49 \mathrm{mmol})$, [1,1'-bis(diphenylphosphino) ferrocene] dichloropalladium(II) complex with dichloromethane $(0.15 \mathrm{~g}, 0.19 \mathrm{mmol})$, and potassium acetate $(1.1 \mathrm{~g}, 11.5 \mathrm{mmol})$ in 1,4 -dioxane $(7.5 \mathrm{~mL})$ was stirred at $80^{\circ} \mathrm{C}$ overnight under argon. The mixture was diluted with THF $(20 \mathrm{~mL})$ and filtered. The filtrate was evaporated to give a dark solid residue, which was used without further purification (LC-MS: $\left.m / z=177.0[\mathrm{M}+\mathrm{H}]^{\dagger}\right)$. The residue was combined with S5 $(0.73 \mathrm{~g}, 3.0 \mathrm{mmol}),\left[1,1^{\prime}-\right.$ bis(diphenylphosphino)ferrocene] dichloropalladium(II) complex with dichloromethane (0.245 $\mathrm{g}, 0.3 \mathrm{mmol})$ and aqueous $2 \mathrm{M} \mathrm{K}_{2} \mathrm{CO}_{3}(4.5 \mathrm{~mL}, 9.0 \mathrm{mmol})$ in $\mathrm{CH}_{3} \mathrm{CN}(9.0 \mathrm{~mL})$. The mixture was stirred at $60{ }^{\circ} \mathrm{C}$ overnight under argon. The mixture was diluted with water and filtered. The 
solid was dissolved in $\mathrm{CH}_{2} \mathrm{Cl}_{2}\left(10 \%\right.$ methanol), dried over $\mathrm{Na}_{2} \mathrm{SO}_{4}$, filtered, concentrated and purified by silica gel chromatography $\left(0-10 \% \mathrm{MeOH}\right.$ in $\left.\mathrm{CH}_{2} \mathrm{Cl}_{2}\right)$ to give $(0.67 \mathrm{~g}, 76 \%)$. LC-MS: $m / z=295.0[\mathrm{M}+\mathrm{H}]^{+}$.

3-(2-Methylimidazo[1,2-a]pyridin-6-yl)-7-(piperazin-1-yl)-2H-chromen-2-one (40). A mixture of S14 (90 mg, $0.31 \mathrm{mmol}$ ), piperazine (129 mg, $1.5 \mathrm{mmol}), \mathrm{K}_{2} \mathrm{CO}_{3}$ (125 mg, 0.92 mmol) in DMSO $(0.6 \mathrm{~mL})$ was stirred at $100^{\circ} \mathrm{C}$ overnight. The mixture was diluted with saturated aqueous $\mathrm{NaHCO}_{3}$ and filtered. The solid was dried and purified by silica gel chromatography $\left(0-10 \% \mathrm{MeOH}\right.$ in $\left.\mathrm{CH}_{2} \mathrm{Cl}_{2}\right)$ to give 40 (56 mg, 46\%) as a yellow solid. LC-MS: $m / z=361.1[\mathrm{M}+\mathrm{H}]^{+} ;{ }^{1} \mathrm{H}$ NMR $\left(500 \mathrm{MHz}\right.$, methanol- $\left.d_{4}\right) \delta 8.88(\mathrm{~s}, 1 \mathrm{H}), 8.09(\mathrm{~s}, 1 \mathrm{H}), 7.79(\mathrm{~s}, 1 \mathrm{H})$, 7.61-7.52 (2H), $7.48(\mathrm{~m}, 1 \mathrm{H}), 7.00(\mathrm{~m}, 1 \mathrm{H}), 6.85(\mathrm{~s}, 1 \mathrm{H}), 3.47-3.40(4 \mathrm{H}), 3.12-3.03(4 \mathrm{H}), 2.43(\mathrm{~s}$, $3 \mathrm{H})$.

Scheme 11, part A
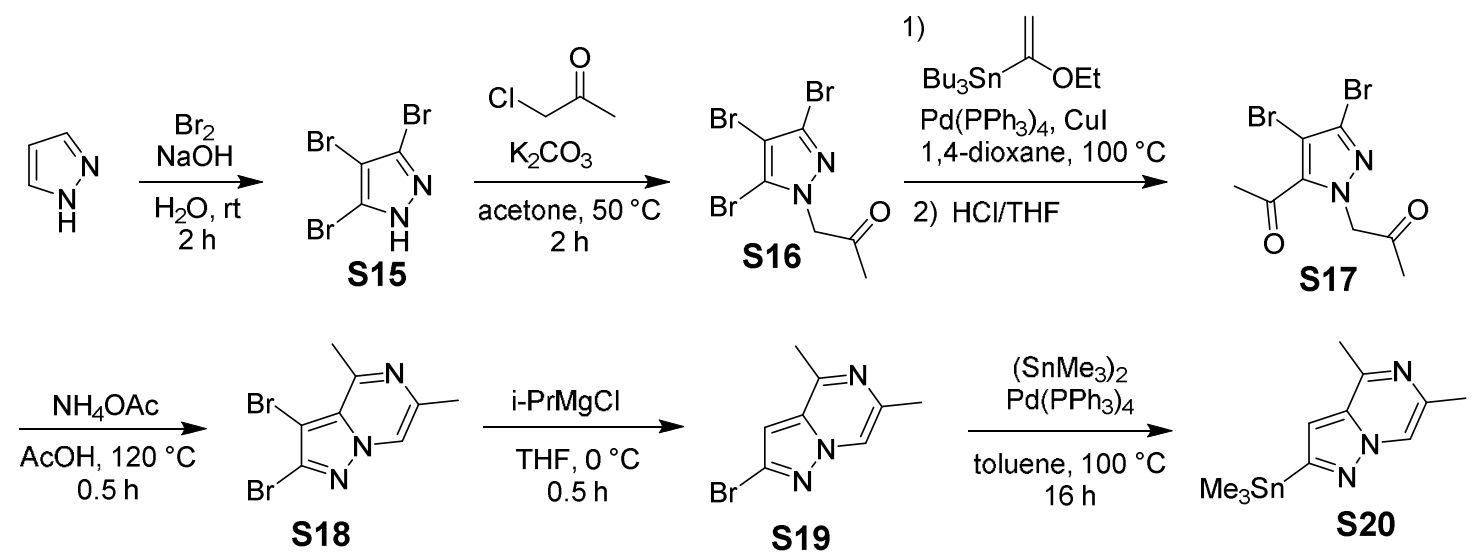

3,4,5-Tribromo-1H-pyrazole (S15). Into a stirred solution of $1 \mathrm{H}$-pyrazole (6.95 g, $0.1 \mathrm{~mol})$ and sodium hydroxide $(16 \mathrm{~g}, 0.4 \mathrm{~mol})$ in water $(400 \mathrm{~mL})$ was added bromine $(48 \mathrm{~g}, 0.3 \mathrm{~mol})$ dropwise over $1 \mathrm{~h}$. The mixture was stirred for $1 \mathrm{~h}$, and then filtered. The cake was washed with water and dried to give $\mathbf{S 1 5}(25.2 \mathrm{~g}, 81 \%)$. LC-MS: $m / z=302.9[\mathrm{M}+\mathrm{H}]^{+}$.

1-(3,4,5-Tribromo-1H-pyrazol-1-yl)propan-2-one (S16). Into a mixture of S15 (1.54 g, $5.1 \mathrm{mmol})$ and $\mathrm{K}_{2} \mathrm{CO}_{3}(2.1 \mathrm{~g}, 15.3 \mathrm{mmol})$ in acetone $(20 \mathrm{~mL})$ was added chloroacetone $(0.52 \mathrm{~g}$, $5.6 \mathrm{mmol})$ dropwise. The mixture stirred at $\mathrm{rt}$ for $2 \mathrm{~h}$, and then was partitioned between water and $\mathrm{CH}_{2} \mathrm{Cl}_{2}$. The organic layer was dried over $\mathrm{Na}_{2} \mathrm{SO}_{4}$ and concentrated to give $\mathbf{S 1 6}$ (1.80 g, 99\%). LC-MS: $m / z=361.0[\mathrm{M}+\mathrm{H}]^{+}$.

1-(5-Acetyl-3,4-dibromo-1H-pyrazol-1-yl)propan-2-one (S17). A mixture of S16 (3.6 g, $10.0 \mathrm{mmol})$, tributyl(1-ethoxyvinyl)stannane $(3.5 \mathrm{~mL}, 10.0 \mathrm{mmol})$ and bis(triphenylphosphine)palladium(II) dichloride $(0.35 \mathrm{~g}, 0.5 \mathrm{mmol})$ in 1,4-dioxane $(25 \mathrm{~mL})$ was stirred at $100{ }^{\circ} \mathrm{C}$ overnight. The reaction was cooled to $\mathrm{rt}$, and then filtered through Celite. The filtrate was concentrated and partitioned between EtOAc $(100 \mathrm{~mL})$ and aqueous $1 \mathrm{~N} \mathrm{HCl} \mathrm{(100}$ $\mathrm{mL})$. The mixture was stirred at $60^{\circ} \mathrm{C}$ for $1 \mathrm{~h}$. The organic layer was then separated And the aqueous layer was extracted with EtOAc $(50 \mathrm{~mL}$ x 3). The combined organic layers were dried 
over $\mathrm{Na}_{2} \mathrm{SO}_{4}$ and concentrated. The residue was chromatographed on silica gel $\left(\mathrm{CH}_{2} \mathrm{Cl}_{2}\right)$ to give S17 (1.1 g, 34\%). LC-MS: $m / z=325.0[\mathrm{M}+\mathrm{H}]^{+}$.

2,3-Dibromo-4,6-dimethylpyrazolo[1,5-a]pyrazine (S18). A mixture of S17 (3.24 g, 10 $\mathrm{mmol})$ and ammonium acetate $(7.7 \mathrm{~g}, 100 \mathrm{mmol})$ in acetic acid $(10 \mathrm{~mL})$ was stirred at $120^{\circ} \mathrm{C}$ for $30 \mathrm{~min}$. The mixture was cooled to $\mathrm{rt}$ and diluted with water $(150 \mathrm{~mL})$. The mixture was stirred for $20 \mathrm{~min}$ and filtered. The solid was dried and chromatographed on silica gel $\left(\mathrm{CH}_{2} \mathrm{Cl}_{2}\right)$ to give S18 $(1.55$ g, $50 \%)$. LC-MS: $m / z=305.9[\mathrm{M}+\mathrm{H}]^{+}$.

2-Bromo-4,6-dimethylpyrazolo[1,5-a]pyrazine (S19). Into a solution of S18 (1.55 g, 5.1 $\mathrm{mmol})$ in THF $(50 \mathrm{~mL})$ at $0{ }^{\circ} \mathrm{C}$ was added a solution of i- $\mathrm{PrMgCl}(2.7 \mathrm{~mL}$ of a $2.0 \mathrm{M}$ solution in THF, $5.4 \mathrm{mmol}$ ). The mixture stirred at $0{ }^{\circ} \mathrm{C}$ for $30 \mathrm{~min}$. Excess reagent was quenched with the addition of methanol $(25 \mathrm{~mL})$. The mixture was partitioned between EtOAc and water. The organic layer was washed with brine, dried over $\mathrm{Na}_{2} \mathrm{SO}_{4}$, concentrated and chromatographed on silica gel, eluting with 0-35\% EtOAc in hexanes to provide (0.95 g, 80\%). LC-MS: $\mathrm{m} / \mathrm{z}=228.1$ $[\mathrm{M}+\mathrm{H}]^{+}$.

\section{4,6-Dimethyl-2-(trimethylstannyl)pyrazolo[1,5-a]pyrazine (S20). A mixture of S19} $(0.226 \mathrm{mg}, 1.0 \mathrm{mmol})$, hexamethyldistannane $(0.397 \mathrm{~g}, 1.2 \mathrm{mmol})$ and tetrakis(triphenylphosphine) palladium $(0)(0.116 \mathrm{~g}, 0.1 \mathrm{mmol})$ in toluene $(3.0 \mathrm{~mL})$ was stirred at $100{ }^{\circ} \mathrm{C}$ overnight under argon. The mixture was cooled to $\mathrm{rt}$ and chromatographed on silica gel (0-45\% EtOAc in hexanes) to give $\mathbf{S 2 0}(0.212 \mathrm{~g}, 70 \%)$ as a white solid. LC-MS: $\mathrm{m} / \mathrm{z}=312.2$ $[\mathrm{M}+\mathrm{H}]^{+} ;{ }^{1} \mathrm{H}$ NMR $\left(500 \mathrm{MHz}\right.$, acetone- $\left.d_{6}\right) \delta 8.29(\mathrm{~s}, 1 \mathrm{H}), 6.95(\mathrm{~s}, 1 \mathrm{H}), 2.66(\mathrm{~s}, 3 \mathrm{H}), 2.42(\mathrm{~d}, J=$ $0.9 \mathrm{~Hz}, 3 \mathrm{H}), 0.36(\mathrm{~s}, 9 \mathrm{H})$.

Scheme 11, part B 


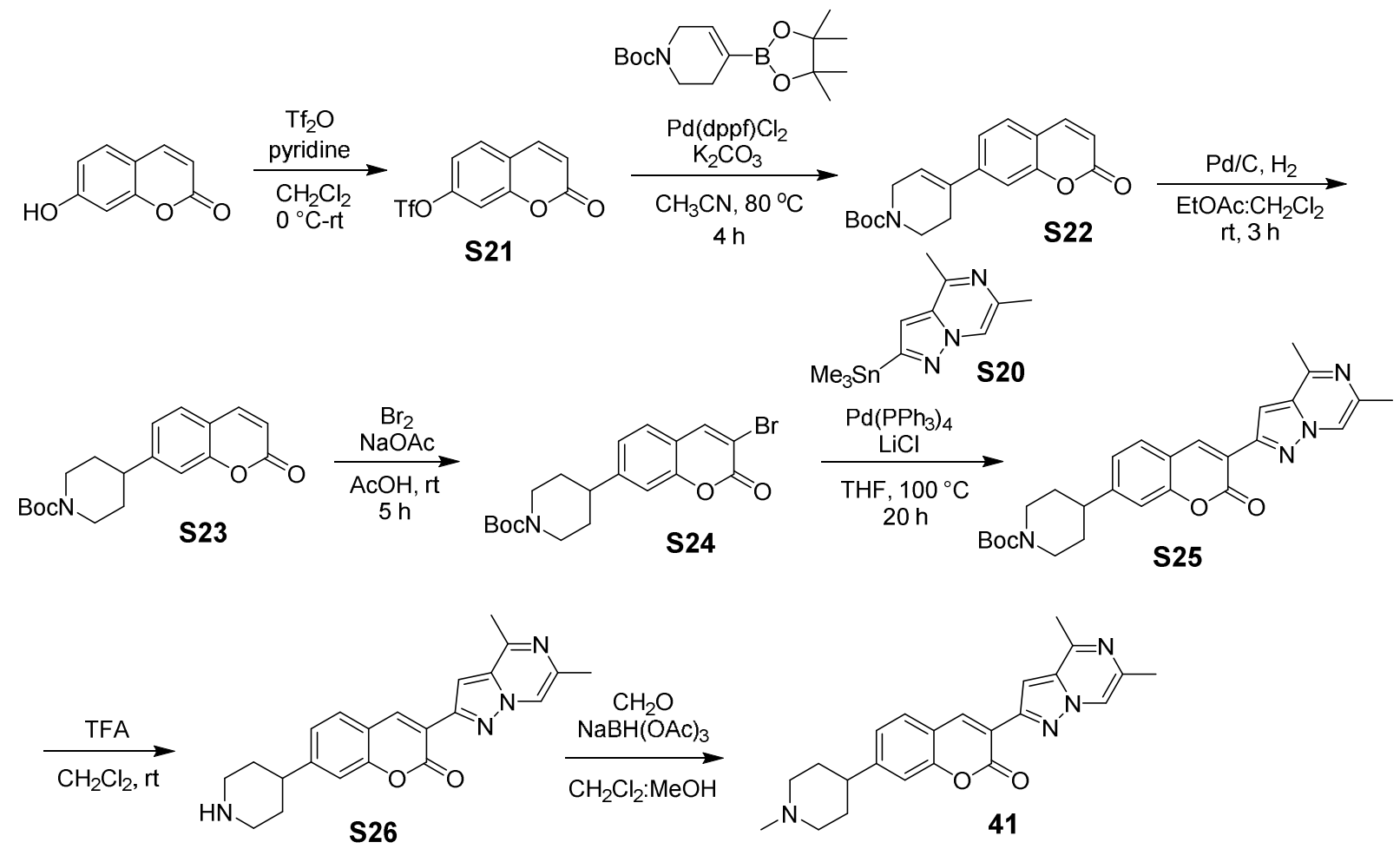

2-Oxo-2H-chromen-7-yl trifluoromethanesulfonate (S21). A solution of triflic anhydride (20.2 mL, $120 \mathrm{mmol})$ in $\mathrm{CH}_{2} \mathrm{Cl}_{2}(50 \mathrm{~mL})$ was added dropwise into a suspension of 7 hydroxycoumarin $(16.2 \mathrm{~g}, 100 \mathrm{mmol})$ in pyridine $(16.3 \mathrm{~mL}, 200 \mathrm{mmol})$ and $\mathrm{CH}_{2} \mathrm{Cl}_{2}(250 \mathrm{ml})$ at 0 ${ }^{\circ} \mathrm{C}$. The mixture was warmed to rt over $30 \mathrm{~min}$. The mixture was washed with dilute aqueous $\mathrm{HCl}$, water, brine, and then dried over $\mathrm{NaSO}_{4}$ and concentrated to give $\mathbf{S 2 1}(28.5 \mathrm{~g}, 97 \%)$ as a tan solid. LC-MS: $m / z=295.0[\mathrm{M}+\mathrm{H}]^{+}$.

tert-Butyl 4-(2-oxo-2H-chromen-7-yl)-5,6-dihydropyridine-1(2H)-carboxylate (S22). A mixture of S21 (2.94 g, $10 \mathrm{mmol}$ ), tert-butyl 4-(4,4,5,5-tetramethyl-1,3,2-dioxaborolan-2-yl)5,6-dihydropyridine-1(2H)-carboxylate (3.7 g, $12 \mathrm{mmol}$ ), [1,1'-bis(diphenylphosphino)ferrocene] dichloropalladium(II) complex with dichloromethane $(0.81 \mathrm{~g}, 1.0 \mathrm{mmol})$ and $\mathrm{K}_{2} \mathrm{CO}_{3}(4.14 \mathrm{~g}, 30$ mmol) in $\mathrm{CH}_{3} \mathrm{CN}(40 \mathrm{~mL})$ was stirred at $80^{\circ} \mathrm{C}$ for $4 \mathrm{~h}$. The mixture was partitioned in water and EtOAc. The organic layer was dried over $\mathrm{Na}_{2} \mathrm{SO}_{4}$, concentrated and chromatographed on silica gel (0-10\% EtOAc in $\left.\mathrm{CH}_{2} \mathrm{Cl}_{2}\right)$ to give $\mathbf{S 2 2}(3.4 \mathrm{~g}, 100 \%)$. LC-MS: $m / z=328.2[\mathrm{M}+\mathrm{H}]^{+}$.

tert-Butyl 4-(2-oxo-2H-chromen-7-yl)piperidine-1-carboxylate (S23). A solution of S22 $(3.4 \mathrm{~g}, 10 \mathrm{mmol})$ in $\mathrm{CH}_{2} \mathrm{Cl}_{2}(50 \mathrm{~mL})$ and EtOAc $(100 \mathrm{~mL})$ was stirred with $5 \% \mathrm{Pd} / \mathrm{C}(0.35$ g) under $\mathrm{H}_{2}(1 \mathrm{~atm})$ at $\mathrm{rt}$ for $3 \mathrm{~h}$. The mixture was filtered. The filtrate was concentrated to give $\mathbf{S 2 3}(3.4 \mathrm{~g}, 100 \%)$. LC-MS: $m / z=330.2[\mathrm{M}+\mathrm{H}]^{+}$.

\section{tert-Butyl 4-(3-bromo-2-oxo-2H-chromen-7-yl)piperidine-1-carboxylate (S24).}

Bromine (2.1 g, $13 \mathrm{mmol})$ was added dropwise at rt into a solution of S23 $(3.4 \mathrm{~g}, 10 \mathrm{mmol})$ and sodium acetate $(2.46 \mathrm{~g}, 30 \mathrm{mmol})$ in acetic acid $(15 \mathrm{~mL})$. The mixture was stirred at $\mathrm{rt}$ for $5 \mathrm{~h}$, and then diluted with water and filtered. The collected solid was dissolved in dichloromethane 
and washed with saturated aqueous $\mathrm{NaHCO}_{3}$. The organic layer was dried over $\mathrm{Na}_{2} \mathrm{SO}_{4}$, concentrated and chromatographed on silica gel $\left(0-10 \%\right.$ EtOAc in $\left.\mathrm{CH}_{2} \mathrm{Cl}_{2}\right)$ to give $\mathbf{S 2 4}(0.9 \mathrm{~g}$, $22 \%) .{ }^{1} \mathrm{H}$ NMR $\left(\mathrm{CDCl}_{3}\right) \delta 8.10(\mathrm{~s}, 1 \mathrm{H}), 7.42(\mathrm{~d}, \mathrm{~J}=7.9 \mathrm{~Hz}, 1 \mathrm{H}), 7.24-7.14(\mathrm{~m}, 2 \mathrm{H}), 4.28(\mathrm{~m}$, 2H), $2.84(\mathrm{~m}, 2 \mathrm{H}), 2.77(\mathrm{~m}, 1 \mathrm{H}), 1.89(\mathrm{~m}, 2 \mathrm{H}), 1.71-1.58(\mathrm{~m}, 2 \mathrm{H}), 1.50(\mathrm{~s}, 9 \mathrm{H})$.

tert-Butyl 4-(3-(4,6-dimethylpyrazolo[1,5-a]pyrazin-2-yl)-2-oxo-2H-chromen-7yl)piperidine-1-carboxylate (S25). A mixture of S24 (110 mg, $0.24 \mathrm{mmol}$ ), 4,6-dimethyl-2(trimethylstannyl)pyrazolo[1,5-a]pyrazine $(75 \mathrm{mg}, 0.24 \mathrm{mmol})$, tetrakis(triphenylphosphine) palladium(0) $(28 \mathrm{mg}, 0.024 \mathrm{mmol})$ in a $0.5 \mathrm{M}$ solution of $\mathrm{LiCl}$ in $\mathrm{THF}(1.44 \mathrm{~mL}, 0.72 \mathrm{mmol})$ was stirred at $100{ }^{\circ} \mathrm{C}$ for $20 \mathrm{~h}$. The volatiles were removed and the residue was chromatographed on silica gel (0-60\% EtOAc in $\mathrm{CH}_{2} \mathrm{Cl}_{2}$ ) to give $\mathbf{S 2 5}$ (98 mg, 86\%). LC-MS: $m / z=475.3$ $[\mathrm{M}+\mathrm{H}]^{+}$.

\section{3-(4,6-Dimethylpyrazolo[1,5-a]pyrazin-2-yl)-7-(piperidin-4-yl)-2H-chromen-2-one}

(S26). A solution of $\mathbf{S 2 5}(98 \mathrm{mg}, 0.21 \mathrm{mmol})$ and TFA $(0.4 \mathrm{~mL})$ in $\mathrm{CH}_{2} \mathrm{Cl}_{2}(0.4 \mathrm{~mL})$ was stirred at $\mathrm{rt}$ for $1 \mathrm{~h}$. The mixture was partitioned between EtOAc and aqueous $1 \mathrm{M} \mathrm{K}_{2} \mathrm{CO}_{3}$. The organic layer was dried over $\mathrm{Na}_{2} \mathrm{SO}_{4}$, filtered and concentrated to give $\mathbf{S 2 6}$ (80 mg, 100\%). LC-MS: $m / z$ $=375.3[\mathrm{M}+\mathrm{H}]^{+}$.

\section{3-(4,6-Dimethylpyrazolo[1,5-a]pyrazin-2-yl)-7-(1-methylpiperidin-4-yl)-2H-chromen-} 2-one (41). A mixture of $\mathbf{S 2 6}(61 \mathrm{mg}, 0.1 \mathrm{mmol})$, formaldehyde (37\% aqueous solution, 0.3 $\mathrm{mL})$ and $\mathrm{NaBH}(\mathrm{OAc})_{3}(64 \mathrm{mg}, 0.3 \mathrm{mmol})$ in $\mathrm{CH}_{2} \mathrm{Cl}_{2} / \mathrm{MeOH}(9 / 1,1 \mathrm{~mL})$ was stirred at rt for 15 min. The reaction was quenched by the addition of aqueous saturated $\mathrm{NaHCO}_{3}$. The mixture was extracted with $\mathrm{CH}_{2} \mathrm{Cl}_{2}(10 \% \mathrm{MeOH})$. The organic layer was dried over $\mathrm{NaSO}_{4}$, filtered, concentrated and then purified by silica gel column chromatography $\left(10 \% \mathrm{MeOH}\right.$ in $\left.\mathrm{CH}_{2} \mathrm{Cl}_{2}\right)$ to give 41 (36 mg, 90\%) as a gray solid. ${ }^{1} \mathrm{H}$ NMR $\left(500 \mathrm{MHz}\right.$, methanol- $\left.d_{4}\right) \delta 8.60(\mathrm{~s}, 1 \mathrm{H}), 8.14(\mathrm{~s}$, $1 \mathrm{H}), 7.58(\mathrm{~d}, J=8.5 \mathrm{~Hz}, 1 \mathrm{H}), 7.52(\mathrm{~s}, 1 \mathrm{H}), 7.24-7.19(2 \mathrm{H}), 3.08(\mathrm{~m}, 2 \mathrm{H}), 2.72-2.65(4 \mathrm{H}), 2.40(\mathrm{~s}$, $3 \mathrm{H}), 2.39(\mathrm{~s}, 3 \mathrm{H}), 2.33(\mathrm{~m}, 2 \mathrm{H}), 1.90(\mathrm{~m}, 2 \mathrm{H}), 1.80(\mathrm{~m}, 2 \mathrm{H})$.

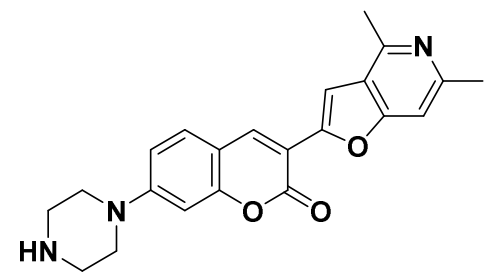

\section{3-(4,6-Dimethylfuro[3,2-c]pyridin-2-yl)-7-(piperazin-1-yl)-2H-chromen-2-one (42).}

Starting from $\mathbf{S 7}$ and 3-iodo-2,6-dimethylpyridin-4-ol, the procedure used to prepare $\mathbf{3 8}$ was used to prepare 42. LC-MS: $m / z=376.3[\mathrm{M}+\mathrm{H}]^{+} ;{ }^{1} \mathrm{H} \mathrm{NMR}\left(500 \mathrm{MHz}, \mathrm{CDCl}_{3}\right) \delta 8.25(\mathrm{~s}, 1 \mathrm{H}), 7.62(\mathrm{~s}$, $1 \mathrm{H}), 7.46(\mathrm{~m}, 1 \mathrm{H}), 7.12(\mathrm{~s}, 1 \mathrm{H}), 6.88(\mathrm{~m}, 1 \mathrm{H}), 6.76(\mathrm{~m}, 1 \mathrm{H}), 3.42(\mathrm{~m}, 2 \mathrm{H}), 3.37(\mathrm{~m}, 2 \mathrm{H}), 3.05$ $(\mathrm{m}, 2 \mathrm{H}), 2.76(\mathrm{~s}, 3 \mathrm{H}), 2.72(\mathrm{~m}, 2 \mathrm{H}), 2.66(\mathrm{~s}, 3 \mathrm{H})$.

Scheme 12 

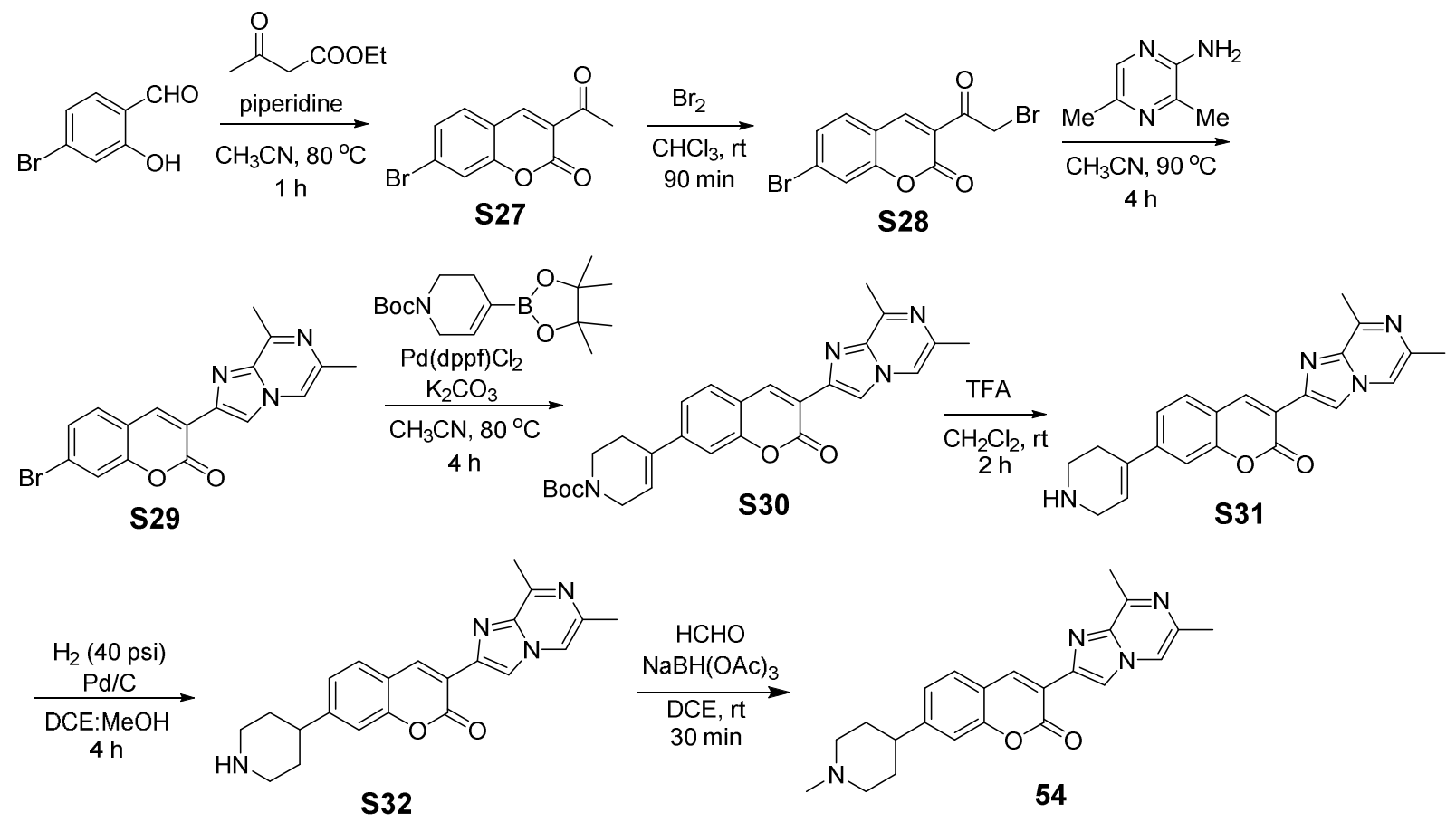

3-Acetyl-7-bromo-2H-chromen-2-one (S27). A mixture of 4-bromo-2-

hydroxybenzaldehyde (5.0 g, $24.8 \mathrm{mmol})$, piperidine $(150 \mu \mathrm{L}, 1.5 \mathrm{mmol})$, ethyl acetoacetate (3.15 mL, $25 \mathrm{mmol})$ and $\mathrm{CH}_{3} \mathrm{CN}(2.0 \mathrm{~mL})$ was heated at $80^{\circ} \mathrm{C}$ for $1 \mathrm{~h}$. The reaction mixture was partitioned between $\mathrm{CH}_{2} \mathrm{Cl}_{2}$ and aqueous $\mathrm{HCl}(1 \mathrm{M})$. The organic layer was dried over $\mathrm{MgSO}_{4}$, filtered, and concentrated under vacuum. The residue was triturated with $\mathrm{MeOH}$, yielding $\mathbf{S 2 7}$ $(5.45 \mathrm{~g}, 82 \%)$ as a yellow solid. ${ }^{1} \mathrm{H} \mathrm{NMR}\left(500 \mathrm{MHz}, \mathrm{CDCl}_{3}\right) \delta 8.46(\mathrm{~s}, 1 \mathrm{H}), 7.56(\mathrm{~d}, J=1.5 \mathrm{~Hz}$, $1 \mathrm{H}), 7.51(\mathrm{~d}, J=8.0 \mathrm{~Hz}, 1 \mathrm{H}), 7.48(\mathrm{dd}, J=8.0,1.5 \mathrm{~Hz}, 1 \mathrm{H}), 2.72(\mathrm{~s}, 3 \mathrm{H})$.

7-Bromo-3-(2-bromoacetyl)-2H-chromen-2-one (S28). A solution of $\mathrm{Br}_{2}(1.1 \mathrm{~mL}, 21.4$ $\mathrm{mmol})$ in $\mathrm{CHCl}_{3}(25 \mathrm{~mL})$ was added dropwise to a solution of $\mathbf{S 2 7}(5.4 \mathrm{~g}, 20.2 \mathrm{mmol})$ in $\mathrm{CHCl}_{3}$ $(90 \mathrm{~mL})$ over a period of $90 \mathrm{~min}$. The mixture was filtered. The solid material was washed with $\mathrm{CHCl}_{3}$ and dried, yielding $\mathbf{S 2 8}(5.6 \mathrm{~g}, 80 \%)$ as a light pink solid. ${ }^{1} \mathrm{H} \mathrm{NMR}\left(500 \mathrm{MHz}, \mathrm{CDCl}_{3}\right) \delta$ $8.58(\mathrm{~s}, 1 \mathrm{H}), 7.60(\mathrm{~d}, J=1.5 \mathrm{~Hz}, 1 \mathrm{H}), 7.55(\mathrm{~d}, J=8.5 \mathrm{~Hz}, 1 \mathrm{H}), 7.52(\mathrm{dd}, J=8.5,1.5 \mathrm{~Hz}, 1 \mathrm{H})$, $4.72(\mathrm{~s}, 2 \mathrm{H})$.

\section{7-Bromo-3-(6,8-dimethylimidazo[1,2-a]pyrazin-2-yl)-2H-chromen-2-one (S29). A} mixture of $\mathbf{S 2 8}$ (2.0 g, $5.78 \mathrm{mmol})$, 2-amino-3,5-dimethylpyrazine ( $825 \mathrm{mg}, 6.71 \mathrm{mmol}$ ) and $\mathrm{CH}_{3} \mathrm{CN}(22 \mathrm{~mL})$ was heated at $90{ }^{\circ} \mathrm{C}$ for $4 \mathrm{~h}$. The addition of aqueous $\mathrm{NaHCO}_{3}$ to the mixture resulted in the formation of a precipitate. The precipitate was collected by vacuum filtration and triturated with 1:1 hexanes/acetone, yielding S29 $(1.9 \mathrm{~g}, 88 \%)$ as an orange solid. ${ }^{1} \mathrm{H}$ NMR (500 MHz, DMSO- $\left.d_{6}\right) \delta 8.81(\mathrm{~s}, 1 \mathrm{H}), 8.61(\mathrm{~s}, 1 \mathrm{H}), 8.31(\mathrm{~s}, 1 \mathrm{H}), 7.93(\mathrm{~d}, J=8.0 \mathrm{~Hz}, 1 \mathrm{H}), 7.76(\mathrm{~d}, J=$ $1.5 \mathrm{~Hz}, 1 \mathrm{H}), 7.58$ (dd, $J=8.0,1.5 \mathrm{~Hz}, 1 \mathrm{H}), 2.76$ (s, 3H), 2.37 (s, 3H).

tert-Butyl 4-(3-(6,8-dimethylimidazo[1,2-a]pyrazin-2-yl)-2-oxo-2H-chromen-7-yl)5,6-dihydropyridine-1(2H)-carboxylate (S30). A mixture of $\mathbf{S 2 9}(1.1 \mathrm{~g}, 2.97 \mathrm{mmol})$, tert- 
butyl 4-(4,4,5,5-tetramethyl-1,3,2-dioxaborolan-2-yl)-5,6-dihydropyridine-1(2H)-carboxylate (1.12 g, $3.62 \mathrm{mmol}), \mathrm{K}_{2} \mathrm{CO}_{3}(1.24 \mathrm{~g}, 9.0 \mathrm{mmol})$, [1,1'-bis(diphenylphosphino)-

ferrocene]dichloropalladium (II) complex with dichloromethane (200 $\mathrm{mg}, 0.24 \mathrm{mmol})$ and $\mathrm{CH}_{3} \mathrm{CN}(8 \mathrm{~mL})$ was heated at $80{ }^{\circ} \mathrm{C}$ for $4 \mathrm{~h}$. The reaction mixture was partitioned between $\mathrm{CH}_{2} \mathrm{Cl}_{2}$ and $\mathrm{H}_{2} \mathrm{O}$. The organic layer was concentrated under vacuum. The residue was purified by silica gel column chromatography (30-50\% acetone in $\mathrm{CH}_{2} \mathrm{Cl}_{2}$ ), followed by trituration with acetone, yielding S30 (1.17 g, 83\%) as a light yellow solid. ${ }^{1} \mathrm{H}$ NMR (500 MHz, DMSO- $\left.d_{6}\right) \delta$ $8.85(\mathrm{~s}, 1 \mathrm{H}), 8.62(\mathrm{~s}, 1 \mathrm{H}), 8.34(\mathrm{~s}, 1 \mathrm{H}), 7.94(\mathrm{~d}, J=8.5 \mathrm{~Hz}, 1 \mathrm{H}), 7.52(\mathrm{~d}, J=8.5 \mathrm{~Hz}, 1 \mathrm{H}), 7.50$ (s, 1H), 6.47 (br s, 1H), 4.07 (br s, 2H), 3.58 (t, J=5.0 Hz, 2H), 2.77 (s, 3H), 2.53 (br s, 2H), 2.38 $(\mathrm{s}, 3 \mathrm{H}), 1.45(\mathrm{~s}, 9 \mathrm{H})$.

\section{3-(6,8-Dimethylimidazo[1,2-a]pyrazin-2-yl)-7-(1,2,3,6-tetrahydropyridin-4-yl)-2H-}

chromen-2-one (S31). A solution of S30 (300 mg, $0.63 \mathrm{mmol})$ in trifluoroacetic acid (1.0 $\mathrm{mL})$ and $\mathrm{CH}_{2} \mathrm{Cl}_{2}(4 \mathrm{~mL})$ was stirred at $\mathrm{rt}$ for $30 \mathrm{~min}$. The reaction mixture was poured into dilute aqueous $\mathrm{NaOH}$. The mixture was extracted with $\mathrm{CH}_{2} \mathrm{Cl}_{2}$. EtOH was added to improve the solubility. The organic layer was collected and concentrated under reduced pressure. The residue was purified by silica gel column chromatography $\left(30 \% \mathrm{MeOH}\right.$ in $\mathrm{CH}_{2} \mathrm{Cl}_{2}$, followed by $10-20 \%$ of 9/1 MeOH/NH$/ \mathrm{NH}_{4} \mathrm{On} \mathrm{CH}_{2} \mathrm{Cl}_{2}$ ) yielding $\mathbf{S 3 1}(183 \mathrm{mg}, 77 \%)$ as a light tan solid. LC-MS: $\mathrm{m} / z$ $=373.1[\mathrm{M}+\mathrm{H}]^{+} ;{ }^{1} \mathrm{H}$ NMR $\left(500 \mathrm{MHz}, \mathrm{DMSO}-d_{6}\right): \delta 8.83(\mathrm{~s}, 1 \mathrm{H}), 8.61(\mathrm{~s}, 1 \mathrm{H}), 8.33(\mathrm{~s}, 1 \mathrm{H}), 7.91$ $(\mathrm{d}, J=8.5 \mathrm{~Hz}, 1 \mathrm{H}), 7.50(\mathrm{dd}, J=8.0,1.5 \mathrm{~Hz}, 1 \mathrm{H}), 7.45(\mathrm{~s}, 1 \mathrm{H}), 6.52(\mathrm{~m}, 1 \mathrm{H}), 3.42(\mathrm{~m}, 2 \mathrm{H}), 2.94$ (t, $J=6.0 \mathrm{~Hz}, 2 \mathrm{H}), 2.77(\mathrm{~s}, 3 \mathrm{H}), 2.40$ (m, 2H), 2.37 (s, 3H), 2.28 (br s, 1H).

\section{3-(6,8-Dimethylimidazo[1,2-a]pyrazin-2-yl)-7-(piperidin-4-yl)-2H-chromen-2-one} (S32). A solution of $\mathbf{S 3 1}$ (133 mg, $0.36 \mathrm{mmol})$ in 1,2-dichloroethane/MeOH (20 mL, 1/1) was stirred in the presence of $10 \%$ palladium on carbon $(\mathrm{Pd} / \mathrm{C}, 107 \mathrm{mg})$ under hydrogen $(40 \mathrm{psi})$. After $4 \mathrm{~h}$, the reaction mixture was filtered through Celite. The filtrate was concentrated under vacuum. The residue was purified by silica gel column chromatography $(10 \% 9 / 1$ $\mathrm{MeOH} / \mathrm{NH}_{4} \mathrm{OH}$ in $\mathrm{CH}_{2} \mathrm{Cl}_{2}$ ), followed by trituration with $1 / 1$ hexanes $/ \mathrm{CH}_{2} \mathrm{Cl}_{2}$, yielding $76 \mathrm{mg}$ $(56 \%)$ of an off-white solid. LC-MS: $m / z=375.1[\mathrm{M}+\mathrm{H}]^{+} ;{ }^{1} \mathrm{H}$ NMR (500 MHz, DMSO- $\left.d_{6}\right) \delta$ $8.84(\mathrm{~s}, 1 \mathrm{H}), 8.61(\mathrm{~s}, 1 \mathrm{H}), 8.34(\mathrm{~s}, 1 \mathrm{H}), 7.90(\mathrm{~d}, J=8.0 \mathrm{~Hz}, 1 \mathrm{H}), 7.30(\mathrm{~m}, 2 \mathrm{H}), 3.05(\mathrm{~d}, J=12.0$ $\mathrm{Hz}, 2 \mathrm{H}), 2.77(\mathrm{~s}, 3 \mathrm{H}), 2.73(\mathrm{tt}, J=12.0,3.5 \mathrm{~Hz}, 1 \mathrm{H}), 2.59(\mathrm{td}, J=12.0,2.5 \mathrm{~Hz}, 2 \mathrm{H}), 2.38(\mathrm{~s}, 3 \mathrm{H})$, 2.20 (br s, 1H), 1.73 (d, $J=12.0 \mathrm{~Hz}, 2 \mathrm{H}), 1.54$ (qd, $J=12.0,3.5 \mathrm{~Hz}, 2 \mathrm{H})$.

\section{3-(6,8-Dimethylimidazo[1,2-a]pyrazin-2-yl)-7-(1-methylpiperidin-4-yl)-2H-chromen- 2-one (54). To a mixture of $\mathbf{S 3 2}$ (104 mg, $0.28 \mathrm{mmol})$, 1,2-dichloroethane (1.0 $\mathrm{mL})$ and aqueous formaldehyde $(37 \%, 0.3 \mathrm{~mL})$ was added sodium triacetoxyborohydride $(150 \mathrm{mg}, 0.71$ $\mathrm{mmol}$ ) in one portion. The mixture was stirred at $\mathrm{rt}$ for $15 \mathrm{~min}$, and then was partitioned between aqueous $\mathrm{K}_{2} \mathrm{CO}_{3}$ and $\mathrm{CH}_{2} \mathrm{Cl}_{2}$. The organic layer was concentrated under vacuum. The residue was chromatographed on silica gel $\left(10 \% \mathrm{MeOH}\right.$ in $\left.\mathrm{CH}_{2} \mathrm{Cl}_{2}\right)$ to yield 54 (52 $\left.\mathrm{mg}, 48 \%\right)$ as an off-white solid. LC-MS: $m / z=389.1[\mathrm{M}+\mathrm{H}]^{+}$; ${ }^{1} \mathrm{H}$ NMR (500 MHz, DMSO- $\left.d_{6}\right) \delta 8.84(\mathrm{~s}, 1 \mathrm{H}), 8.61(\mathrm{~s}$, $1 \mathrm{H}), 8.34(\mathrm{~s}, 1 \mathrm{H}), 7.90(\mathrm{~d}, J=8.0 \mathrm{~Hz}, 1 \mathrm{H}), 7.35(\mathrm{~s}, 1 \mathrm{H}), 7.32(\mathrm{dd}, J=8.0,1.5 \mathrm{~Hz}, 1 \mathrm{H}), 2.90(\mathrm{~m}$, $2 \mathrm{H}), 2.77(\mathrm{~s}, 3 \mathrm{H}), 2.61(\mathrm{~m}, 1 \mathrm{H}), 2.37(\mathrm{~s}, 3 \mathrm{H}), 2.21(\mathrm{~s}, 3 \mathrm{H}), 1.99(\mathrm{~m}, 2 \mathrm{H}), 1.75(\mathrm{~m}, 4 \mathrm{H})$.}


Scheme 13, part A

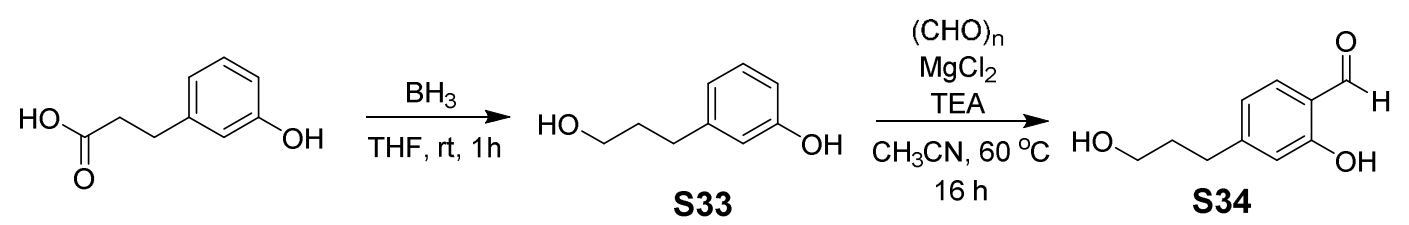

3-(3-Hydroxypropyl)phenol (S33). A solution of borane-tetrahydrofuran complex in THF $(1 \mathrm{M}, 180 \mathrm{~mL})$ was added to a solution of 3-(3-hydroxyphenyl)propanoic acid $(15.0 \mathrm{~g}, 90 \mathrm{mmol})$ in THF $(200 \mathrm{~mL})$ at $\mathrm{rt}$. The mixture was stirred at $50^{\circ} \mathrm{C}$ for $1 \mathrm{~h}$. The excess reagent was quenched at $0{ }^{\circ} \mathrm{C}$ by the addition of $10 \mathrm{~mL} \mathrm{H}_{2} \mathrm{O}$. The THF was removed by rotary evaporation under reduced pressure. The residue was partitioned in EtOAc $(400 \mathrm{~mL})$ and saturated aqueous $\mathrm{NaHCO}_{3}(200 \mathrm{~mL})$. The organic layer was washed with brine, dried over $\mathrm{Na}_{2} \mathrm{SO}_{4}$, filtered and concentrated to yield S33 (8.9 g, 66\%). LC-MS: $\mathrm{m} / z=151.1[\mathrm{M}-\mathrm{H}]^{+} ;{ }^{1} \mathrm{H}$ NMR $(500 \mathrm{MHz}$, $\left.\mathrm{CDCl}_{3}\right) \delta 7.18(\mathrm{t}, J=7.9 \mathrm{~Hz}, 1 \mathrm{H}), 6.80(\mathrm{~d}, J=7.6 \mathrm{~Hz}, 1 \mathrm{H}), 6.72-6.67(2 \mathrm{H}), 3.70(\mathrm{~m}, 2 \mathrm{H}), 2.70$ (m, 2H), $1.92(\mathrm{~m}, 2 \mathrm{H})$.

2-Hydroxy-4-(3-hydroxypropyl)benzaldehyde (S34). A mixture of $\mathbf{S 3 3}$ (8.90 g, 59 $\mathrm{mmol})$, triethylamine $(70 \mathrm{~mL}, 118 \mathrm{mmol})$ and anhydrous magnesium chloride $(19.0 \mathrm{~g}, 118$ $\mathrm{mmol})$ were combined in THF $(200 \mathrm{~mL})$. The mixture was stirred for $5 \mathrm{~min}$ at $50^{\circ} \mathrm{C}$ before the addition of paraformaldehyde $(30 \mathrm{~g}, 177 \mathrm{mmol})$. The mixture was then stirred at reflux for $18 \mathrm{~h}$. The volatiles were removed from the mixtureand the residue was partitioned in EtOAc $(400 \mathrm{~mL})$ and saturated aqueous $1 \mathrm{M} \mathrm{HCl}(200 \mathrm{~mL})$. The organic layer was washed with brine, dried over $\mathrm{Na}_{2} \mathrm{SO}_{4}$, filtered and concentrated. The residue was chromatographed on silica gel $(0-50 \%$ EtOAc in hexanes) to yield $\mathbf{S 3 4}(3.8 \mathrm{~g}, 36 \%)$ as a colorless oil. MS $m / z 179.1[\mathrm{M}-\mathrm{H}]^{+} .{ }^{1} \mathrm{H}$ NMR $\left(500 \mathrm{MHz}, \mathrm{CDCl}_{3}\right) \delta 11.07(\mathrm{~s}, 1 \mathrm{H}), 9.87(\mathrm{~s}, 1 \mathrm{H}), 7.49(\mathrm{~d}, J=7.9 \mathrm{~Hz}, 1 \mathrm{H}), 6.89(\mathrm{~d}, J=7.7 \mathrm{~Hz}$, $1 \mathrm{H}), 6.71(\mathrm{~s}, 1 \mathrm{H}), 3.71(\mathrm{~m}, 2 \mathrm{H}), 2.77(\mathrm{~m}, 2 \mathrm{H}), 1.93(\mathrm{~m}, 2 \mathrm{H})$.

Scheme 13, part B

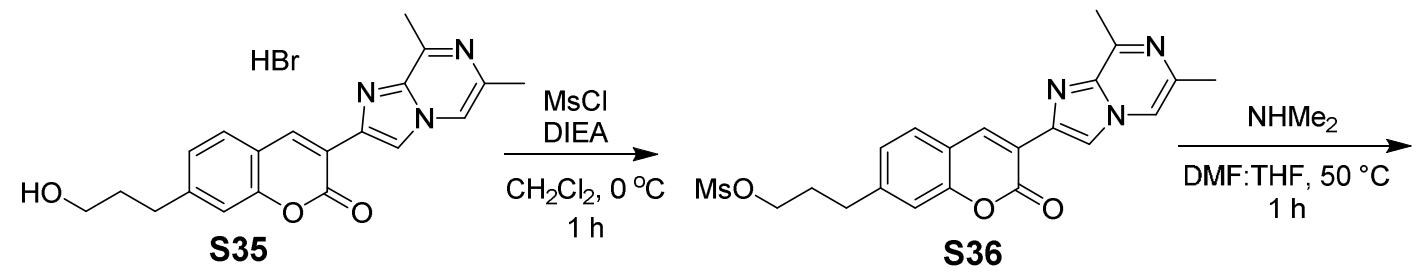<smiles>Cc1cnc(-c2cc3ccc(CCCN(C)C)cc3oc2=O)nc1C</smiles>

3-(6,8-dimethylimidazo[1,2-a]pyrazin-2-yl)-7-(3-hydroxypropyl)-2H-chromen-2-one (S35). Following the procedure found in Scheme 2, S34 (600 mg, $3.3 \mathrm{mmol})$ was converted to S35 (320 mg, $0.77 \mathrm{mmol})$. MS $m / z 377.3[\mathrm{M}+\mathrm{H}]^{+} .{ }^{1} \mathrm{H}$ NMR (500 MHz, DMSO- $\left.d_{6}\right) \delta 8.86(\mathrm{~s}$, $1 \mathrm{H}), 8.64(\mathrm{~s}, 1 \mathrm{H}), 8.35(\mathrm{~s}, 1 \mathrm{H}), 7.86(\mathrm{~d}, J=8.2 \mathrm{~Hz}, 1 \mathrm{H}), 7.31(\mathrm{~m}, 1 \mathrm{H}), 7.28$ (dd, $J=8.0,1.6 \mathrm{~Hz}$, 
$1 \mathrm{H}), 4.53(\mathrm{t}, J=5.0 \mathrm{~Hz}, 1 \mathrm{H}), 3.43(\mathrm{q}, J=5.0 \mathrm{~Hz}, 2 \mathrm{H}), 2.76(\mathrm{~m}, 2 \mathrm{H}), 2.59(\mathrm{~s}, 3 \mathrm{H}), 2.51(3 \mathrm{H}$, under DMSO peak), 1.77 (m, 2H).

\section{3-(3-(6,8-Dimethylimidazo[1,2-a]pyrazin-2-yl)-2-oxo-2H-chromen-7-yl)propyl}

methanesulfonate (S36). To a mixture of $\mathbf{S 3 5}(320 \mathrm{~g}, 0.77 \mathrm{mmol}), \mathrm{N}, \mathrm{N}$ -

diisopropylethylamine $(0.4 \mathrm{~mL}, 2.3 \mathrm{mmol})$ and $\mathrm{CH}_{2} \mathrm{Cl}_{2}(4 \mathrm{~mL})$ was added methanesulfonyl

chloride $(0.12 \mathrm{~mL}, 1.54 \mathrm{mmol})$ at $0{ }^{\circ} \mathrm{C}$. The mixture was stirred for $30 \mathrm{~min}$ at $0{ }^{\circ} \mathrm{C}$ and then was loaded directly to silica gel, eluting with $0-5 \% \mathrm{MeOH}$ in $\mathrm{CH}_{2} \mathrm{Cl}_{2}$ to afford $\mathbf{S 3 6}(170 \mathrm{mg}, 52 \%)$ as a white powder. MS $m / z 428.2[\mathrm{M}+\mathrm{H}]^{+}$.

\section{7-(3-(Dimethylamino)propyl)-3-(6,8-dimethylimidazo[1,2-a]pyrazin-2-yl)-2H-}

chromen-2-one (55). To a mixture of $\mathbf{S 3 6}$ (30 $\mathrm{mg}, 0.07 \mathrm{mmol}$ ) and THF/DMF (1/1, $1 \mathrm{~mL}$ ) was added a $2 \mathrm{M}$ solution of dimethylamine in THF $(0.5 \mathrm{~mL}, 0.5 \mathrm{mmol})$. The mixture was stirred at $50{ }^{\circ} \mathrm{C}$ for $24 \mathrm{~h}$. The mixture was loaded directly onto silica gel and eluted with $0-10 \% \mathrm{MeOH}$ (containing 3\% $\mathrm{NH}_{3}$ ) in $\mathrm{CH}_{2} \mathrm{Cl}_{2}$ to afford $\mathbf{5 5}(21 \mathrm{mg}, 80 \%$ ) as an off white powder: $\mathrm{mp}$ 192-196 ${ }^{\circ} \mathrm{C}$; MS $\left.m / z 377.3[\mathrm{M}+\mathrm{H}]\right]^{+} ;{ }^{1} \mathrm{H}$ NMR $\left(500 \mathrm{MHz}\right.$, DMSO- $\left.d_{6}\right) \delta 8.86(\mathrm{~s}, 1 \mathrm{H}), 8.62(\mathrm{~s}, 1 \mathrm{H}), 8.35(\mathrm{~s}$, $1 \mathrm{H}), 7.90(\mathrm{~d}, J=7.9 \mathrm{~Hz}, 1 \mathrm{H}), 7.34(\mathrm{~s}, 1 \mathrm{H}), 7.28(\mathrm{~d}, J=7.9 \mathrm{~Hz}, 1 \mathrm{H}), 2.78(\mathrm{~s}, 3 \mathrm{H}), 2.73(\mathrm{~m}, 2 \mathrm{H})$, $2.38(\mathrm{~s}, 3 \mathrm{H}), 2.23(\mathrm{~m}, 2 \mathrm{H}), 2.14(\mathrm{~s}, 6 \mathrm{H}), 1.76(\mathrm{~m}, 2 \mathrm{H})$.

Scheme 14<smiles>CC(C)(C)OC(=O)N1CCN(c2cccc(O)n2)CC1</smiles><smiles></smiles>

tert-Butyl-4-(6-hydroxypyridin-2-yl)piperazine-1-carboxylate (S37). To a solution of 2chloro-6-hydroxypyridine $(12.3 \mathrm{~g}, 94 \mathrm{mmol})$ in $n$ - $\mathrm{BuOH}(50 \mathrm{~mL})$ was added $t$-butyl piperazine1-carboxylate $(46.0 \mathrm{~g}, 235 \mathrm{mmol})$. The mixture was heated at $140{ }^{\circ} \mathrm{C}$ for $3 \mathrm{~d}$. The reaction mixture was extracted with ethyl acetate $(1.5 \mathrm{~L})$ and washed with saturated aqueous $\mathrm{NH}_{4} \mathrm{Cl}$ and brine. The organic layer was dried over $\mathrm{MgSO}_{4}$, filtered and concentrated under reduced pressure. The resulting solid was dissolved in $\mathrm{CH}_{3} \mathrm{CN}(100 \mathrm{~mL})$ and precipitated by adding water $(1 \mathrm{~L})$. The precipitate was collected by filtration, washed with water and ether, and dried. Additionally, the organic layer of the filtrate was separated and concentrated under reduced pressure. The residue was purified by column chromatography (50-100\% EtOAc in hexanes) and combined with the filtered solid, giving a $\mathbf{S 3 7}(18.7 \mathrm{~g}, 71 \%)$ as a white solid. LC-MS: $\mathrm{m} / \mathrm{z}=$ 
$280.2[\mathrm{M}+\mathrm{H}]^{+} ;{ }^{1} \mathrm{H}$ NMR $\left(500 \mathrm{MHz}, \mathrm{CDCl}_{3}\right) \delta 7.40(\mathrm{~m}, 1 \mathrm{H}), 6.04(\mathrm{~d}, J=8.8 \mathrm{~Hz}, 1 \mathrm{H}), 5.64(\mathrm{~d}, J$ $=7.2 \mathrm{~Hz}, 1 \mathrm{H}), 3.62(\mathrm{~m}, 4 \mathrm{H}), 3.36(\mathrm{~m}, 4 \mathrm{H}), 1.51(\mathrm{~s}, 9 \mathrm{H})$.

tert-Butyl-4-(5-formyl-6-hydroxypyridin-2-yl)piperazine-1-carboxylate (S38). To a mixture of $\mathbf{S 3 7}(8.4 \mathrm{~g}, 30 \mathrm{mmol})$ and $\mathrm{MgCl}_{2}(5.8 \mathrm{~g}, 60 \mathrm{mmol})$ in $\mathrm{CH}_{3} \mathrm{CN}(100 \mathrm{~mL})$ was added triethylamine $(25.2 \mathrm{~mL}, 150 \mathrm{mmol})$. After the mixture had stirred for 10 minutes at $\mathrm{rt}$, paraformaldehyde $(9.0 \mathrm{~g}, 300 \mathrm{mmol})$ was added. The mixture was stirred at $60^{\circ} \mathrm{C}$ for $18 \mathrm{~h}$. After cooling to rt, the mixture was diluted with EtOAc $(500 \mathrm{~mL})$ and washed with $1 \mathrm{M}$ aqueous Rochelle salt $(200 \mathrm{~mL})$ and saturated aqueous $\mathrm{NH}_{4} \mathrm{Cl}(200 \mathrm{~mL})$. The organic layer was concentrated under reduced pressure and purified by column chromatography $(30-50 \%$ EtOAc in hexanes) to yield $\mathbf{S 3 8}$ (3.6 g, 39\%) of as white solid. LC-MS: $m / z=308.2[\mathrm{M}+\mathrm{H}]{ }^{+} ;{ }^{1} \mathrm{H}$ NMR $\left(500 \mathrm{MHz}, \mathrm{CDCl}_{3}\right) \delta 12.35(\mathrm{br} \mathrm{s}, 1 \mathrm{H}), 9.55(\mathrm{~s}, 1 \mathrm{H}), 7.66(\mathrm{~d}, J=8.5 \mathrm{~Hz}, 1 \mathrm{H}), 6.26(\mathrm{~d}, J=8.8 \mathrm{~Hz}$, $1 \mathrm{H}), 3.79(\mathrm{~m}, 4 \mathrm{H}), 3.56(\mathrm{~m}, 4 \mathrm{H}), 1.51(\mathrm{~s}, 9 \mathrm{H})$.

\section{tert-Butyl 4-(3-(3,4-dimethoxyphenyl)-2-oxo-2H-pyrano[2,3-b]pyridin-7- \\ yl)piperazine-1-carboxylate (S39). To a mixture of $\mathbf{S 3 8}(62 \mathrm{mg}, 0.2 \mathrm{mmol})$ and 2-(3,4-}

dimethoxyphenyl)acetic acid ( $78 \mathrm{mg}, 0.4 \mathrm{mmol})$ in DMF $(0.5 \mathrm{~mL})$ were added EDCI $(77 \mathrm{mg}, 0.4$ mmol) and DIPEA $(0.13 \mathrm{~mL}, 0.8 \mathrm{mmol})$. The mixture was then stirred at $60{ }^{\circ} \mathrm{C}$ for $14 \mathrm{~h}$. After cooling to $\mathrm{rt}$, the mixure was diluted with EtOAc $(10 \mathrm{~mL})$ and washed with saturated aqueous $\mathrm{NaHCO}_{3}(10 \mathrm{~mL})$ and saturated aqueous $\mathrm{NH}_{4} \mathrm{Cl}(10 \mathrm{~mL})$. The organic layer was concentrated under reduced pressure and purified by column chromatography (30-90\% EtOAc in hexanes) to yield S39 (40 mg, 43\%) of as yellow solid. LC-MS: $m / z=468.4[\mathrm{M}+\mathrm{H}]]^{+}$; ${ }^{1} \mathrm{H}$ NMR $(500 \mathrm{MHz}$, $\left.\mathrm{CDCl}_{3}\right) \delta$ 7.63-7.53 (m, 2H), $7.24(\mathrm{~d}, J=2.2 \mathrm{~Hz}, 1 \mathrm{H}), 7.17(\mathrm{dd}, J=8.3,2.1 \mathrm{~Hz}, 1 \mathrm{H}), 6.85(\mathrm{~d}, J=$ $8.5 \mathrm{~Hz}, 1 \mathrm{H}), 6.51(\mathrm{~d}, J=8.8 \mathrm{~Hz}, 1 \mathrm{H}), 3.87$ (s, 3H), $3.85(\mathrm{~s}, 3 \mathrm{H}), 3.66(\mathrm{~m}, 4 \mathrm{H}), 3.50(\mathrm{~m}, 4 \mathrm{H}), 1.43$ (s, 9H).

3-(3,4-Dimethoxyphenyl)-7-(piperazin-1-yl)-2H-pyrano[2,3-b]pyridin-2-one (56). To a solution of $\mathbf{S 3 9}$ in $\mathrm{CH}_{2} \mathrm{Cl}_{2}(2 \mathrm{~mL})$ was added a solution of $4 \mathrm{~N} \mathrm{HCl}$ in dioxane $(0.5 \mathrm{~mL})$. The mixture was stirred for $2 \mathrm{~h}$ at $\mathrm{rt}$. The precipitate was filtered off and washed by ether several times to give 38 (34 mg, 99\%) as yellow solid. LC-MS: $\mathrm{m} / \mathrm{z}=368.5[\mathrm{M}+\mathrm{H}]]^{+} ;{ }^{1} \mathrm{H}$ NMR (500 MHz, DMSO- $\left.d_{6}\right) \delta 9.28(\mathrm{br} \mathrm{s}, 2 \mathrm{H}), 8.16(\mathrm{~s}, 1 \mathrm{H}) 8.00(\mathrm{~d}, J=8.5 \mathrm{~Hz}, 1 \mathrm{H}) 7.36-7.27(\mathrm{~m}, 2 \mathrm{H}), 7.01$ (dd, $J=12.9,8.8 \mathrm{~Hz}, 2 \mathrm{H}), 3.96-3.87$ (m, 4H), 3.81 (s, 3H), 3.80 (s, 3H), 3.22 (d, $J=3.1 \mathrm{~Hz}, 4 \mathrm{H})$.

Scheme 15 

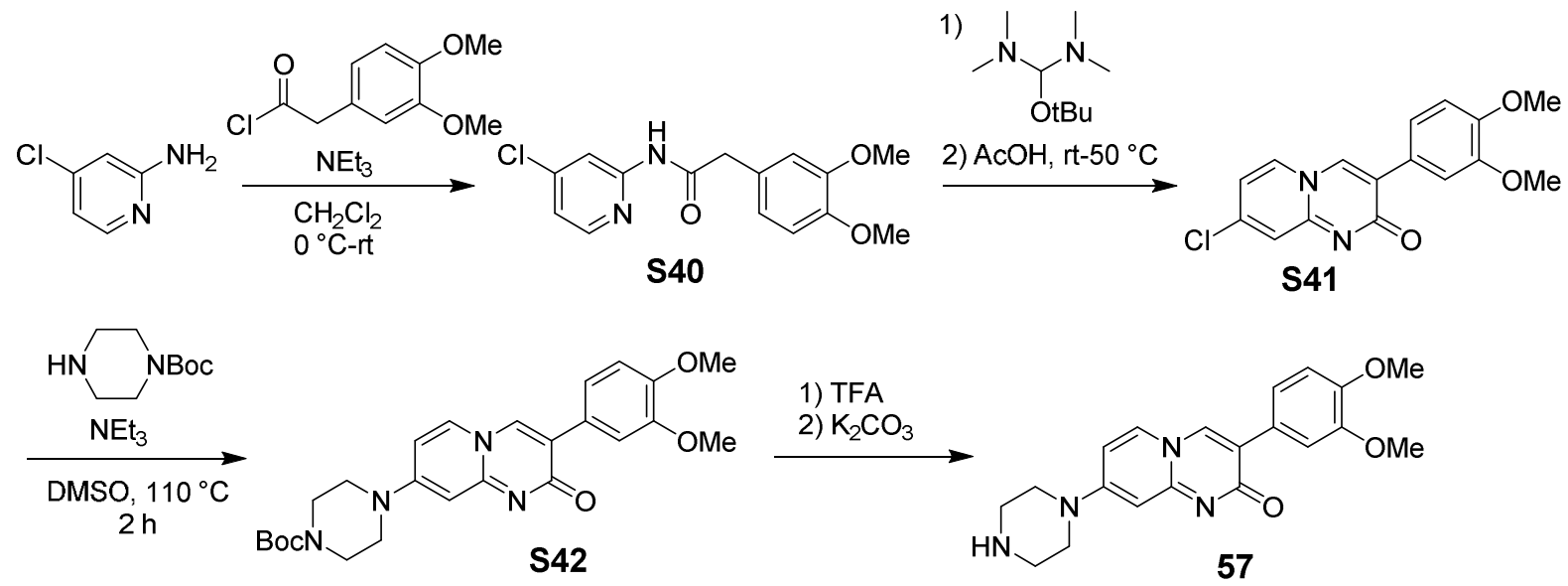

N-(4-Chloropyridin-2-yl)-2-(3,4-dimethoxyphenyl)acetamide (S40). To a mixture of 4chloropyridin-2-amine $(640 \mathrm{mg}, 5 \mathrm{mmol})$ and $\mathrm{CH}_{2} \mathrm{Cl}_{2}(15 \mathrm{~mL})$ was added 2-(3,4dimethoxyphenyl)acetyl chloride $(1.08 \mathrm{~g}, 5 \mathrm{mmol})$ in $\mathrm{CH}_{2} \mathrm{Cl}_{2}(5 \mathrm{~mL})$ at $0{ }^{\circ} \mathrm{C}$. After $10 \mathrm{~min}$, triethylamine $(0.7 \mathrm{~mL}, 5 \mathrm{mmol})$ was added to the mixture. The mixture stirred at $\mathrm{rt}$ for $30 \mathrm{~min}$. The volatiles were removed from the mixture and the residue was chromatographed on silica gel $\left(0-10 \% \mathrm{MeOH}\right.$ in $\left.\mathrm{CH}_{2} \mathrm{Cl}_{2}\right)$ to yield $\mathbf{S 4 0}(1.16 \mathrm{~g}, 76 \%)$ as a yellow oil. $\mathrm{LC}-\mathrm{MS}: m / z=307.2$, $309.1[\mathrm{M}+\mathrm{H}]^{+}$.

8-Chloro-3-(3,4-dimethoxyphenyl)-2H-pyrido[1,2-a]pyrimidin-2-one (S41). A mixture of $\mathbf{S 4 0}$ (307 mg, $1 \mathrm{mmol}$ ) and tert-Butoxy-bis(dimethyamino)-methane (174 mg, $1 \mathrm{mmol}$ ) was heated at $100^{\circ} \mathrm{C}$ for $15 \mathrm{~min}$. After cooling the mixture to rt, $\mathrm{AcOH}(1 \mathrm{~mL})$ was added. The mixture was stirred at $50{ }^{\circ} \mathrm{C}$ for $20 \mathrm{~min}$. To the mixture was added a solution of $\mathrm{MeOH} / \mathrm{H}_{2} \mathrm{O}$ $(4 / 1,5 \mathrm{~mL})$. The mixture was the filtered. The solid was dried to yield $\mathbf{S 4 1}(250 \mathrm{mg}, 79 \%)$. LC-MS: $m / z=317.1,319.1[\mathrm{M}+\mathrm{H}]^{+} .{ }^{1} \mathrm{H}$ NMR $\left(500 \mathrm{MHz}\right.$, DMSO- $\left.d_{6}\right) \delta 8.62(\mathrm{~s}, 1 \mathrm{H}), 8.27(\mathrm{~d}, J$ $=7.2 \mathrm{~Hz}, 1 \mathrm{H}), 7.46(\mathrm{~d}, J=2.2 \mathrm{~Hz}, 1 \mathrm{H}), 7.41(\mathrm{dd}, J=8.1,2.2 \mathrm{~Hz}, 1 \mathrm{H}), 7.35(\mathrm{~d}, J=2.2 \mathrm{~Hz}, 1 \mathrm{H})$, 7.14 (dd, $J=7.2,2.2 \mathrm{~Hz}, 1 \mathrm{H}), 7.05$ (d, $J=8.3 \mathrm{~Hz}, 1 \mathrm{H}), 3.81$ (s, 6H).

tert-Butyl 4-(3-(3,4-dimethoxyphenyl)-2-oxo-2H-pyrido[1,2-a]pyrimidin-8yl)piperazine-1-carboxylate (S42). A mixture of $\mathbf{S 4 1}$ (32 $\mathrm{mg}, 0.10 \mathrm{mmol})$, triethylamine (14 $\mu \mathrm{L}, 0.10 \mathrm{mmol})$, tert-butyl piperazine-1-carboxylate $(174 \mathrm{mg}, 0.10 \mathrm{mmol})$ and DMSO $(0.5 \mathrm{~mL})$ was heated at $110{ }^{\circ} \mathrm{C}$ for $2 \mathrm{~h}$. The mixture was partitioned in $\mathrm{CH}_{2} \mathrm{Cl}_{2}(10 \mathrm{~mL})$ and $\mathrm{H}_{2} \mathrm{O}(10 \mathrm{~mL})$. The organic layer was concentrated and chromatographed on silica gel $\left(10 \% \mathrm{MeOH}\right.$ in $\left.\mathrm{CH}_{2} \mathrm{Cl}_{2}\right)$ to afford S42 (42 mg, 90\%). LC-MS: $m / z=467.3[\mathrm{M}+\mathrm{H}]^{+}$.

\section{3-(3,4-Dimethoxyphenyl)-8-(piperazin-1-yl)-2H-pyrido[1,2-a]pyrimidin-2-one (57).} Compound S42 (42 mg, $0.09 \mathrm{mmol}$ was dissolved in TFA $(1 \mathrm{~mL})$. After $10 \mathrm{~min}$, the volatiles were removed from the reaction mixture with a stream of $\mathrm{N}_{2}$. The residue was dissolved in $1 \mathrm{M}$ aqueous $\mathrm{K}_{2} \mathrm{CO}_{3}(1 \mathrm{~mL})$. The volatiles were removed from the mixture and the residue was washed with $\mathrm{CH}_{2} \mathrm{Cl}_{2}(5 \mathrm{~mL})$. sThe combined organic filtrate was concentrated, yielding 57 (16 $\mathrm{mg}, 48 \%)$ as an off-white powder. LC-MS: $m / z=367.2[\mathrm{M}+\mathrm{H}]^{+} .{ }^{1} \mathrm{H}$ NMR $(500 \mathrm{MHz}$, DMSO$\left.d_{6}\right) \delta 8.34(\mathrm{~s}, 1 \mathrm{H}), 8.02(\mathrm{~d}, J=7.9 \mathrm{~Hz}, 1 \mathrm{H}), 7.43(\mathrm{~d}, J=1.9 \mathrm{~Hz}, 1 \mathrm{H}), 7.34(\mathrm{dd}, J=8.4,2.0 \mathrm{~Hz}$, 
$1 \mathrm{H}), 6.99(\mathrm{~d}, J=8.5 \mathrm{~Hz}, 1 \mathrm{H}), 6.16(\mathrm{~d}, J=2.5 \mathrm{~Hz}, 1 \mathrm{H}), 3.79(\mathrm{~s}, 6 \mathrm{H}), 3.40-3.36(4 \mathrm{H}), 2.82-2.78$ (4H).

Scheme 16<smiles>CCOC(=O)C(=O)c1ccc(OC)c(OC)c1</smiles><smiles>O=C(O)CC(=O)O</smiles>

(n)<smiles>COc1ccc(C(=O)C(=O)O)cc1OC</smiles>

S43

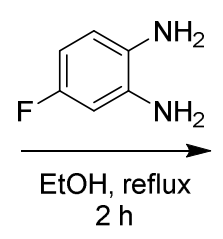

$2 \mathrm{~h}$<smiles>COc1ccc(-c2nc3ccc(F)cc3[nH]c2=O)cc1OC</smiles>

+ the undesired 6-F isomer

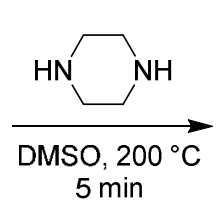<smiles>COc1ccc(-c2nc3ccc(N4CCNCC4)cc3[nH]c2=O)cc1OC</smiles>

2-(3,4-Dimethoxyphenyl)-2-oxoacetic acid (S43). To a solution of ethyl 2-(3,4dimethoxyphenyl)-2-oxoacetate (3.0 g, $12.5 \mathrm{mmol}$, prepared according to Synthesis 2006, 2103) in THF $(32 \mathrm{~mL})$ and water $(16 \mathrm{~mL})$ was added lithium hydroxide $(0.9 \mathrm{~g}, 37.5 \mathrm{mmol})$. The mixutre was stirred at $\mathrm{rt}$ for $3 \mathrm{~h}$, and then poured into ice with aqueous conc. $\mathrm{HCl}(37 \%, 3.5 \mathrm{~mL})$. The mixture was extracted with ethyl acetate. The combined organics were washed with water, dried over $\mathrm{Na}_{2} \mathrm{SO}_{4}$, filtered and concentrated. The residue was triturated with diethyl ether and collected by filtration to provide the $\mathbf{S 4 3}$ (1.6 g, 61\%) as a white solid. LC-MS: $m / z=209.1$ [M$\mathrm{H}]^{+}$.

3-(3,4-Dimethoxyphenyl)-7-fluoroquinoxalin-2(1H)-one (S44). A mixture of S43 (0.80 $\mathrm{g}, 3.3 \mathrm{mmol})$ and 4-fluorobenzene-1,2-diamine (0.42 g, $3.3 \mathrm{mmol})$ in EtOH (6 ml) was stirred at reflux for $2 \mathrm{~h}$. The reaction mixture was cooled and filtered to give a mixture of two isomers $(0.70 \mathrm{~g})$, which were used in the next step without further purification. LC-MS: $m / z=301.2$ $[\mathrm{M}+\mathrm{H}]^{+}$.

\section{3-(3,4-Dimethoxyphenyl)-7-(piperazin-1-yl)quinoxalin-2(1H)-one (58). A mixture of} S44 (100 $\mathrm{mg}, 0.33 \mathrm{mmol})$ and piperazine $(30 \mathrm{mg}, 0.35 \mathrm{mmol})$ in DMSO $(0.5 \mathrm{~mL})$ was irradiated in a microwave reactor at $200{ }^{\circ} \mathrm{C}$ for $5 \mathrm{~min}$. The reaction mixture was cooled and then loaded onto basic alumina eluting with $0-10 \% \mathrm{MeOH}$ in $\mathrm{CH}_{2} \mathrm{Cl}_{2}$ to give 58 (31 mg, 26\%). LC-MS: $\mathrm{m} / z$ $=367.3[\mathrm{M}+\mathrm{H}]^{+} ;{ }^{1} \mathrm{H}$ NMR $\left(500 \mathrm{MHz}, \mathrm{DMSO}-d_{6}\right) \delta 11.27(\mathrm{br} \mathrm{s}, 1 \mathrm{H}), 7.98(\mathrm{dd}, J=8.5,2.0 \mathrm{~Hz}$, $1 \mathrm{H}), 7.87(\mathrm{~d}, J=2.0 \mathrm{~Hz}, 1 \mathrm{H}), 7.49(\mathrm{~d}, J=9.0 \mathrm{~Hz}, 1 \mathrm{H}), 6.92-6.88(\mathrm{~m}, 2 \mathrm{H}), 6.50(\mathrm{~d}, J=3.0 \mathrm{~Hz}$, 1H), 3.70 (s, 3H), $3.18(\mathrm{~s}, 3 \mathrm{H}), 3.08(\mathrm{~m}, 4 \mathrm{H}), 2.73(\mathrm{~m}, 4 \mathrm{H})$.

Scheme 17 

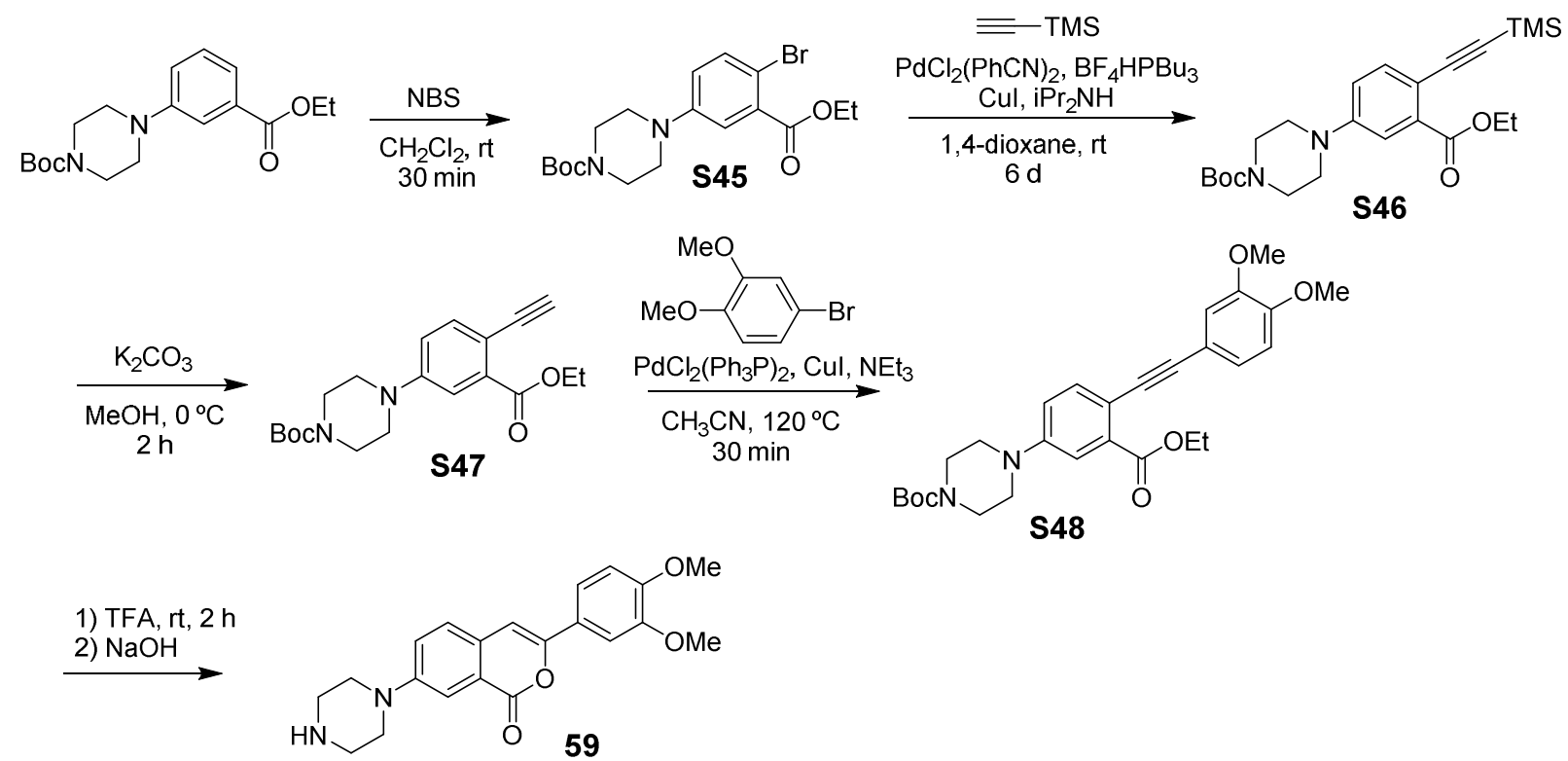

tert-Butyl 4-(4-bromo-3-(ethoxycarbonyl)phenyl)piperazine-1-carboxylate (S45). NBromosuccinimide $(8.5 \mathrm{~g}, 48 \mathrm{mmol})$ was added portion wise to a solution of tert-butyl 4-(3(ethoxycarbonyl)-phenyl)piperazine-1-carboxylate (13.4 g, $40.0 \mathrm{mmol})$ in $\mathrm{CH}_{2} \mathrm{Cl}_{2}(200 \mathrm{~mL})$ at rt. The mixture was then stirred at $\mathrm{rt}$ for $0.5 \mathrm{~h}$. To the mixture was added saturated aqueous $\mathrm{Na}_{2} \mathrm{CO}_{3}$ $(100 \mathrm{~mL})$. The mixture was stirred for an additional $15 \mathrm{~min}$. The organic layer was separated and dried over $\mathrm{Na}_{2} \mathrm{SO}_{4}$, filtered and concentrated. The residue was chromatographed on a silica gel (0-50\% EtOAc in hexanes) to yield $\mathbf{S 4 5}$ as colorless oil (14.2 g, 86\%). LC-MS: $\mathrm{m} / \mathrm{z}=412.4$, $414.4[\mathrm{M}+\mathrm{H}]^{+}$.

\section{tert-Butyl 4-(3-(ethoxycarbonyl)-4-((trimethylsilyl)ethynyl)phenyl)piperazine-1- carboxylate (S46). A $250 \mathrm{~mL}$ round bottom flask was charged with $\mathrm{PdCl}_{2}\left(\mathrm{PhCN}_{2}\right)_{2}(0.51 \mathrm{~g}$,} $1.33 \mathrm{mmol}), \mathrm{PBu}_{3} \mathrm{HBF}_{4}(0.77 \mathrm{~g}, 2.66 \mathrm{mmol})$ and $\mathrm{CuI}(0.20 \mathrm{~g}, 1.06 \mathrm{mmol})$, and purged with argon three times. To the flask was added 1,4-dioxane $(30 \mathrm{~mL})$ and diisopropylamine $(5.6 \mathrm{~mL}, 40.0$ $\mathrm{mmol})$. After the mixture had stirred for $30 \mathrm{~min}$ at $\mathrm{rt}, \mathbf{S 4 5}(11.0 \mathrm{~g}, 26.6 \mathrm{mmol})$ and TMSacetylene $(4.51 \mathrm{~mL}, 32.0 \mathrm{mmol})$ were added. The mixture was stirred at $\mathrm{rt}$ for $6 \mathrm{~d}$. The mixture was filtered. The solid was washed with EtOAc and the combined filtrate was concentrated. The residue was chromatographed on silica gel (0-70\% EtOAc in hexanes) to provide $\mathbf{S 4 6}$ (8.73 g, $76 \%)$ as a brown oil. LC-MS: $m / z=431.4[\mathrm{M}+\mathrm{H}]^{+}$.

tert-Butyl 4-(3-(ethoxycarbonyl)-4-ethynylphenyl)piperazine-1-carboxylate (S47). A mixture of $\mathbf{S 4 6}(3.10 \mathrm{~g}, 7.21 \mathrm{mmol}), \mathrm{K}_{2} \mathrm{CO}_{3}(1.49 \mathrm{~g}, 10.8 \mathrm{mmol})$ and $\mathrm{MeOH}(40 \mathrm{~mL})$ was stirred at $0{ }^{\circ} \mathrm{C}$ for $2 \mathrm{~h}$. To the mixture was added saturated aqueous $\mathrm{NH}_{4} \mathrm{Cl}(20 \mathrm{~mL})$ and EtOAc $(200$ $\mathrm{mL})$. The organic layer was removed. The aqueous layer was extracted with EtOAc $(3 \times 30 \mathrm{~mL})$. The combined organic layers were concentrated and chromatographed on silica gel (0-10\% EtOAc in hexanes) to give $\mathbf{S 4 7}(1.65 \mathrm{~g}, 64 \%)$ as a brown oil. LC-MS: $m / z=359.3[\mathrm{M}+\mathrm{H}]^{+} ;{ }^{1} \mathrm{H}$ $\operatorname{NMR}\left(500 \mathrm{MHz}, \mathrm{CDCl}_{3}\right) \delta 7.51(\mathrm{~d}, J=8.5 \mathrm{~Hz}, 1 \mathrm{H}), 7.44(\mathrm{~d}, J=2.8 \mathrm{~Hz}, 1 \mathrm{H}), 7.00(\mathrm{~m}, 1 \mathrm{H}), 4.41$ (q, $J=7.2 \mathrm{~Hz}, 2 \mathrm{H}), 3.64-3.57$ (m, 4H), 3.27-3.21 (m, 5H), 1.49 (s, 9H), 1.41 (t, $J=7.1 \mathrm{~Hz}, 3 \mathrm{H})$. 


\section{tert-Butyl 4-(4-((3,4-dimethoxyphenyl)ethynyl)-3-(ethoxycarbonyl)}

phenyl)piperazine-1-carboxylate (S48). A mixture of $\mathbf{S 4 7}$ (3.58 g, $10.0 \mathrm{mmol}), 3,4-$

dimethoxybromobenzene ( $2.60 \mathrm{~g}, 12.0 \mathrm{mmol}), \mathrm{CuI}(0.095 \mathrm{~g}, 0.5 \mathrm{mmol}), \mathrm{PdCl}_{2}\left(\mathrm{Ph}_{3} \mathrm{P}\right)_{2}(0.35 \mathrm{~g}$, $0.5 \mathrm{mmol}), \mathrm{Et}_{3} \mathrm{~N}(2.8 \mathrm{~mL}, 2.02 \mathrm{~g}, 20.0 \mathrm{mmol})$ and $\mathrm{CH}_{3} \mathrm{CN}(10.0 \mathrm{~mL})$ was irradiated in a microwave reactor under argon at $120^{\circ} \mathrm{C}$ for $30 \mathrm{~min}$. The mixture was concentrated and chromatographed on silica gel (0-70\% EtOAc in hexanes) to give a brown oil, which was then chromatographed again on silica gel $\left(0-10 \%\right.$ EtOAc in $\left.\mathrm{CH}_{2} \mathrm{Cl}_{2}\right)$ to give $\mathbf{S 4 8}$ as a colorless oil. LC-MS: $m / z=495.2[\mathrm{M}+\mathrm{H}]^{+}$.

3-(3,4-Dimethoxyphenyl)-7-(piperazin-1-yl)-1H-isochromen-1-one (59). Compound $\mathbf{S 4 8}$ from the previous step was combined with TFA $(10.0 \mathrm{~mL})$ at $\mathrm{rt}$. The mixture was stirred at $\mathrm{rt}$ for $1 \mathrm{~h}$, and then was diluted with water $(50 \mathrm{~mL})$. The aqueous mixture was neutralized with $\mathrm{NaHCO}_{3}$ to $\mathrm{pH}$ 8-9, generating a precipitate. The solid was collected, washed with water and dried to provide $59\left(1.26 \mathrm{~g}, 34 \%\right.$ over 2 steps) as a yellow powder: mp $142-143{ }^{\circ} \mathrm{C}$; LC-MS: $\mathrm{m} / z$ $=367.2[\mathrm{M}+\mathrm{H}]^{+} ;{ }^{1} \mathrm{H}$ NMR $\left(500 \mathrm{MHz}, \mathrm{DMSO}-d_{6}\right) \delta 7.59-7.52(2 \mathrm{H}), 7.46(\mathrm{~d}, J=1.6 \mathrm{~Hz}, 1 \mathrm{H})$, $7.42(\mathrm{dd}, J=8.5,2.2 \mathrm{~Hz}, 1 \mathrm{H}), 7.38(\mathrm{~d}, J=2.2 \mathrm{~Hz}, 1 \mathrm{H}), 7.32(\mathrm{~s}, 1 \mathrm{H}), 7.08(\mathrm{~d}, J=8.8 \mathrm{~Hz}, 1 \mathrm{H})$, $3.86(\mathrm{~s}, 3 \mathrm{H}), 3.81$ (s, 3H), 3.22-3.15 (m, 4H), 2.89-2.82 (m, 4H).

Scheme 18

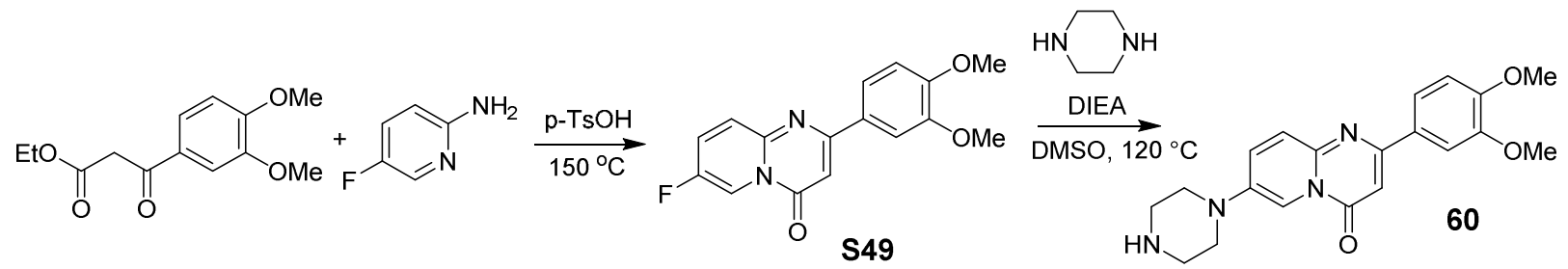

2-(3,4-Dimethoxyphenyl)-7-fluoro-4H-pyrido[1,2-a]pyrimidin-4-one (S49). A mixture of ethyl 3-(3,4-dimethoxyphenyl)-3-oxopropanoate (2.02 g, $8.0 \mathrm{mmol})$, 2-amino-5fluoropyridine $(0.897 \mathrm{~g}, 8.0 \mathrm{mmol})$ and $p-\mathrm{TsOH}(152 \mathrm{mg}, 0.8 \mathrm{mmol})$ was heated at $150^{\circ} \mathrm{C}$. The mixture melted and then solidified. After $1 \mathrm{~h}$, the mixture was cooled to $\mathrm{rt}$ and suspended in $\mathrm{CH}_{3} \mathrm{CN}$. The solid material was collected and dried to give $\mathbf{S 4 9}(1.36 \mathrm{~g}, 56 \%)$ as a yellow solid. LC-MS: $m / z=301.2[\mathrm{M}+\mathrm{H}]^{+} ;{ }^{1} \mathrm{H}$ NMR $\left(500 \mathrm{MHz}\right.$, DMSO- $\left.d_{6}\right) \delta 8.92(1 \mathrm{H}, \mathrm{dd}, J=2.9 \mathrm{~Hz}, 4.8$ $\mathrm{Hz}), 8.11-8.07(1 \mathrm{H}, \mathrm{m}), 7.85-7.82(1 \mathrm{H}, \mathrm{m}), 7.77(1 \mathrm{H}, \mathrm{d}, J=2.1 \mathrm{~Hz}), 7.09(1 \mathrm{H}, \mathrm{d}, J=8.6 \mathrm{~Hz})$, $7.06(1 \mathrm{H}, \mathrm{s}), 6.93(1 \mathrm{H}, \mathrm{s}), 3.88(3 \mathrm{H}, \mathrm{s}), 3.84(3 \mathrm{H}, \mathrm{s})$,

\section{2-(3,4-Dimethoxyphenyl)-7-(piperazin-1-yl)-4H-pyrido[1,2-a]pyrimidin-4-one (60). A} mixture of S49 (1.50 g, $5.0 \mathrm{mmol})$, piperazine $(1.29 \mathrm{~g}, 15 \mathrm{mmol})$ and DIEA $(1.3 \mathrm{~mL}, 7.5 \mathrm{mmol})$ in DMSO $(10 \mathrm{~mL})$ was heated at $120^{\circ} \mathrm{C}$. After $15 \mathrm{~h}$, the volatiles were removed and the residue was washed with $\mathrm{MeCN}$ to give $\mathbf{6 0}(1.67 \mathrm{~g}, 91 \%)$ as a yellow solid: mp 192-194 ${ }^{\circ} \mathrm{C}$; $\mathrm{LC}-\mathrm{MS}$ : $m / z=367.5[\mathrm{M}+\mathrm{H}]^{+} ;{ }^{1} \mathrm{H}$ NMR $\left(500 \mathrm{MHz}\right.$, DMSO- $\left.d_{6}\right) \delta 8.20(\mathrm{~d}, J=2.7 \mathrm{~Hz}, 1 \mathrm{H}), 8.04(\mathrm{dd}, J=$ 9.8, $2.8 \mathrm{~Hz}, 1 \mathrm{H}), 7.79(\mathrm{dd}, J=8.5,2.1 \mathrm{~Hz}, 1 \mathrm{H}), 7.74(\mathrm{~d}, J=2.1 \mathrm{~Hz}, 1 \mathrm{H}), 7.67(\mathrm{~d}, J=9.7 \mathrm{~Hz}$, $1 \mathrm{H}), 7.07$ (d, $J=8.5 \mathrm{~Hz}, 1 \mathrm{H}), 6.93(\mathrm{~s}, 1 \mathrm{H}), 3.87(\mathrm{~s}, 3 \mathrm{H}), 3.83(\mathrm{~s}, 3 \mathrm{H}), 3.12(\mathrm{~m}, 4 \mathrm{H}), 2.88(\mathrm{~m}$, $4 \mathrm{H})$. 
Scheme 19
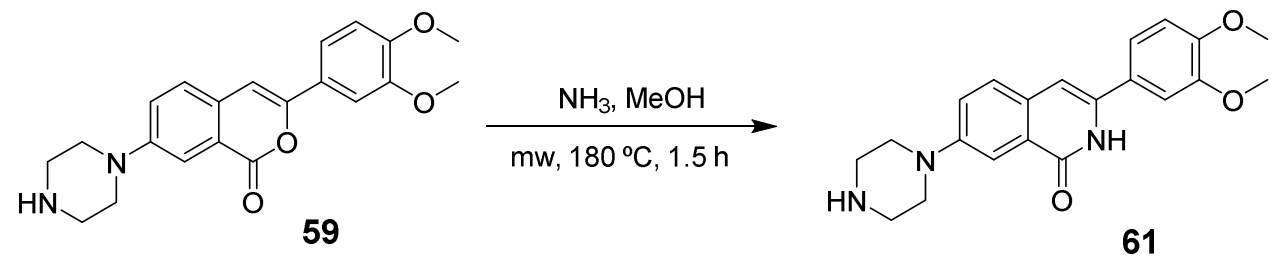

3-(3,4-Dimethoxyphenyl)-7-(piperazin-1-yl)isoquinolin-1(2H)-one (61). A mixture of $59(91.5 \mathrm{mg}, 0.25 \mathrm{mmol})$ and $7.0 \mathrm{M}$ ammonia in methanol $(1.0 \mathrm{~mL})$ was irradiated in a microwave reactor at $180^{\circ} \mathrm{C}$ for $1.5 \mathrm{~h}$. The volatiles were removed and the residue was triturated with acetone to furnish $61(56 \mathrm{mg}, 62 \%)$ as a yellow powder. LC-MS: $\mathrm{m} / z=366.1[\mathrm{M}+\mathrm{H}]{ }^{+} ;{ }^{1} \mathrm{H}$ NMR (500 MHz, DMSO- $\left.d_{6}\right) \delta 11.27(\mathrm{br} \mathrm{s}, 1 \mathrm{H}), 7.56(\mathrm{~d}, J=8.8 \mathrm{~Hz}, 1 \mathrm{H}), 7.51(\mathrm{~d}, J=2.5 \mathrm{~Hz}$, $1 \mathrm{H}), 7.45(\mathrm{dd}, J=8.8,2.8 \mathrm{~Hz}, 1 \mathrm{H}), 7.37-7.31(\mathrm{~m}, 2 \mathrm{H}), 7.03(\mathrm{~d}, J=8.5 \mathrm{~Hz}, 1 \mathrm{H}), 6.82(\mathrm{~s}, 1 \mathrm{H})$, 3.87 (s, 3H), 3.80 (s, 3H), 3.19-3.13 (m, 4H), 2.91-2.83 (m, 4H).

Scheme 20, Part A

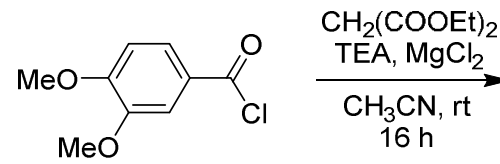

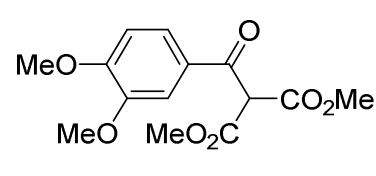

S50

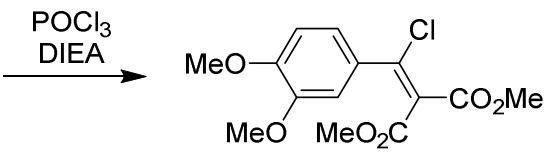

S51

Dimethyl 2-(3,4-dimethoxybenzoyl)malonate (S50). A mixture of diethyl malonate (3.4 $\mathrm{mL}, 30 \mathrm{mmol})$ and triethylamine $(8.3 \mathrm{~mL}, 60 \mathrm{mmol})$ was added dropwise at $0{ }^{\circ} \mathrm{C}$ to a suspension of $\mathrm{MgCl}_{2}(2.85 \mathrm{~g}, 30 \mathrm{mmol})$ in $\mathrm{CH}_{3} \mathrm{CN}(27 \mathrm{~mL})$. The mixture was stirred at $0{ }^{\circ} \mathrm{C}$ for $30 \mathrm{~min} .3,4-$ Dimethoxybenzoyl chloride $(5.0 \mathrm{~g}, 25 \mathrm{mmol})$ was added portionwise to the mixture. After the mixture had stirred at $\mathrm{rt}$ for $16 \mathrm{~h}$, aqueous $1 \mathrm{~N} \mathrm{HCl}$ was added. The mixture was extracted with ether. The organic layer was dried over $\mathrm{Na}_{2} \mathrm{SO}_{4}$, filtered and concentrated. The residue was chromatographed on silica gel (5-40\% EtOAc in hexanes) to give $\mathbf{S 5 0}$ (7.38 g, 100\%). LC-MS: $m / z=297.1[\mathrm{M}+\mathrm{H}]^{+}$.

\section{2-(Chloro(3,4-dimethoxyphenyl)methylene)malonate (S51). N,N-}

Diisopropylethylamine $(2.75 \mathrm{~mL}, 16.7 \mathrm{mmol})$ was added dropwise to a solution of $\mathbf{S 5 0}(2.96 \mathrm{~g}$, $10 \mathrm{mmol})$ in $\mathrm{POCl}_{3}(9.4 \mathrm{~mL}, 100 \mathrm{mmol})$ at rt. The mixture was stirred at $100{ }^{\circ} \mathrm{C}$ for $3 \mathrm{~h}$. The volatiles were removed under vacuum and the residue was suspended in ice-water and extracted with ether. The organic layer was washed with $1 \mathrm{~N} \mathrm{HCl}$, dried over $\mathrm{Na}_{2} \mathrm{SO}_{4}$, filtered and concentrated. The residue was chromatographed on silica gel (5-50\% EtOAc in hexanes) to give S51 (2.0 g, 64\%). LC-MS: $m / z=282.9[\mathrm{M}+\mathrm{H}-\mathrm{MeOH}]^{+}$.

Scheme 20, Part B 


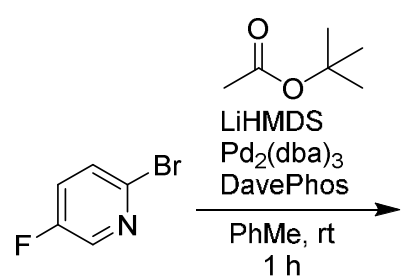

$1 \mathrm{~h}$

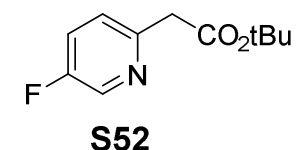

S52

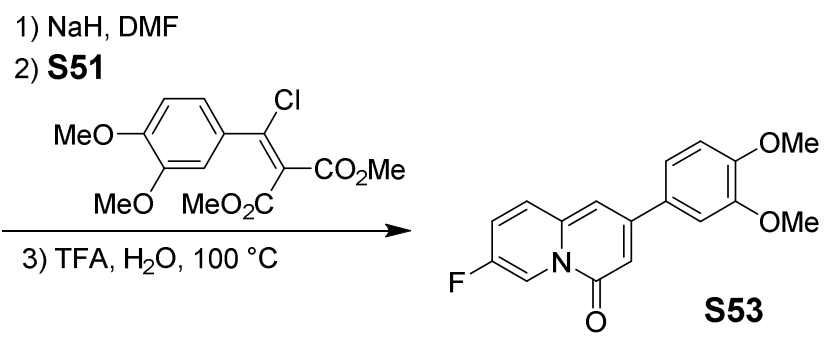<smiles>COc1ccc(-c2cc(=O)n3cc(N4CCNCC4)ccc3c2)cc1OC</smiles>

tert-Butyl 2-(5-fluoropyridin-2-yl)acetate (S52). A solution of lithium

bis(trimethylsilyl)amide in hexane $(50 \mathrm{~mL}, 1.0 \mathrm{M}, 50 \mathrm{mmol})$ was added dropwise under argon at rt to a mixture of $\mathrm{Pd}_{2}(\mathrm{dba})_{3}(0.55 \mathrm{~g}, 0.6 \mathrm{mmol})$ and DavePhos $(0.50 \mathrm{~h}, 1.26 \mathrm{mmol})$ in toluene (40 $\mathrm{mL})$. The mixture was stirred for $10 \mathrm{~min}$ and then cooled to $-10{ }^{\circ} \mathrm{C}$. To the mixture was added tert-butyl acetate $(6.2 \mathrm{~mL}, 46 \mathrm{mmol})$. The mixture was stirred $10 \mathrm{~min}$ before adding 2-bromo-5fluoropyridine $(3.52 \mathrm{~g}, 20 \mathrm{mmol})$ portionwise. The temperature was allowed to rise to rt. After stirring the mixture for $1 \mathrm{~h}$, excess reagent was quenched by the addition of saturated aqueous $\mathrm{NH}_{4} \mathrm{Cl}$. The mixture was extracted with EtOAc. The organic layer was washed with brine, dried over $\mathrm{Na}_{2} \mathrm{SO}_{4}$, filtered and concentrated. The residue was chromatographed on silica gel $(0-20 \%$ EtOAc in hexanes) to give S52 (2.6 g, 62\%).

2-(3,4-Dimethoxyphenyl)-7-fluoro-4H-quinolizin-4-one (S53). To a solution of S52 (211 $\mathrm{mg}, 1.0 \mathrm{mmol})$ in DMF (1 mL) was added $\mathrm{NaH}(60 \%$ in mineral oil, $80 \mathrm{mg}, 2 \mathrm{mmol})$. After the mixture had stirred at $\mathrm{rt}$ for $10 \mathrm{~min}, \mathbf{S 5 1}(320 \mathrm{mg}, 1.0 \mathrm{mmol})$ was added. The mixture was stirred for $15 \mathrm{~min}$ at $\mathrm{rt}$, before adding aqueous saturated $\mathrm{NH}_{4} \mathrm{Cl}$ to quench excess reagent. The mixture was filtered and the solid was washed with water and dried. The solid was dissolved in TFA (5 $\mathrm{mL})$ and $\mathrm{H}_{2} \mathrm{O}(2 \mathrm{~mL})$. The resulting mixture was heated at $100{ }^{\circ} \mathrm{C}$ overnight. Volatiles were removed under vacuum providing $\mathbf{S 5 3}$ (145 mg, 48\%). LC-MS: $m / z=300.2[\mathrm{M}+\mathrm{H}]^{+}$.

2-(3,4-Dimethoxyphenyl)-7-(piperazin-1-yl)-4H-quinolizin-4-one (62). A mixture of S53 (75 mg, $0.25 \mathrm{mmol})$, piperazine $(75 \mathrm{mg}, 0.87 \mathrm{mmol})$ and DMSO $(0.5 \mathrm{~mL})$ was stirred at 120 ${ }^{\circ} \mathrm{C}$ overnight. The solvent was removed with a stream of $\mathrm{N}_{2}$. The residue was chromatographed on silica gel $\left(10 \% \mathrm{MeOH}\right.$ in $\left.\mathrm{CH}_{2} \mathrm{Cl}_{2}\right)$ to provide $62(30 \mathrm{mg}, 33 \%): \mathrm{mp} 278-280{ }^{\circ} \mathrm{C}$; $\mathrm{LC}-\mathrm{MS}: \mathrm{m} / z$ $=366.1[\mathrm{M}+\mathrm{H}]^{+} ;{ }^{1} \mathrm{H} \mathrm{NMR}\left(500 \mathrm{MHz}, \mathrm{CDCl}_{3}\right) \delta 8.53(\mathrm{~d}, J=2.2 \mathrm{~Hz}, 1 \mathrm{H}), 7.46(\mathrm{~d}, J=9.5 \mathrm{~Hz}$, 1H), 7.32-7.27 (m, 2H), $7.22(\mathrm{~d}, J=1.9 \mathrm{~Hz}, 1 \mathrm{H}), 6.97(\mathrm{~d}, J=8.5 \mathrm{~Hz}, 1 \mathrm{H}), 6.84(\mathrm{~s}, 2 \mathrm{H}), 3.98(\mathrm{~s}$, $3 \mathrm{H}), 3.95(\mathrm{~s}, 3 \mathrm{H}), 3.25-3.20(\mathrm{~m}, 4 \mathrm{H}), 3.13-3.07(\mathrm{~m}, 4 \mathrm{H})$.

Scheme 21 

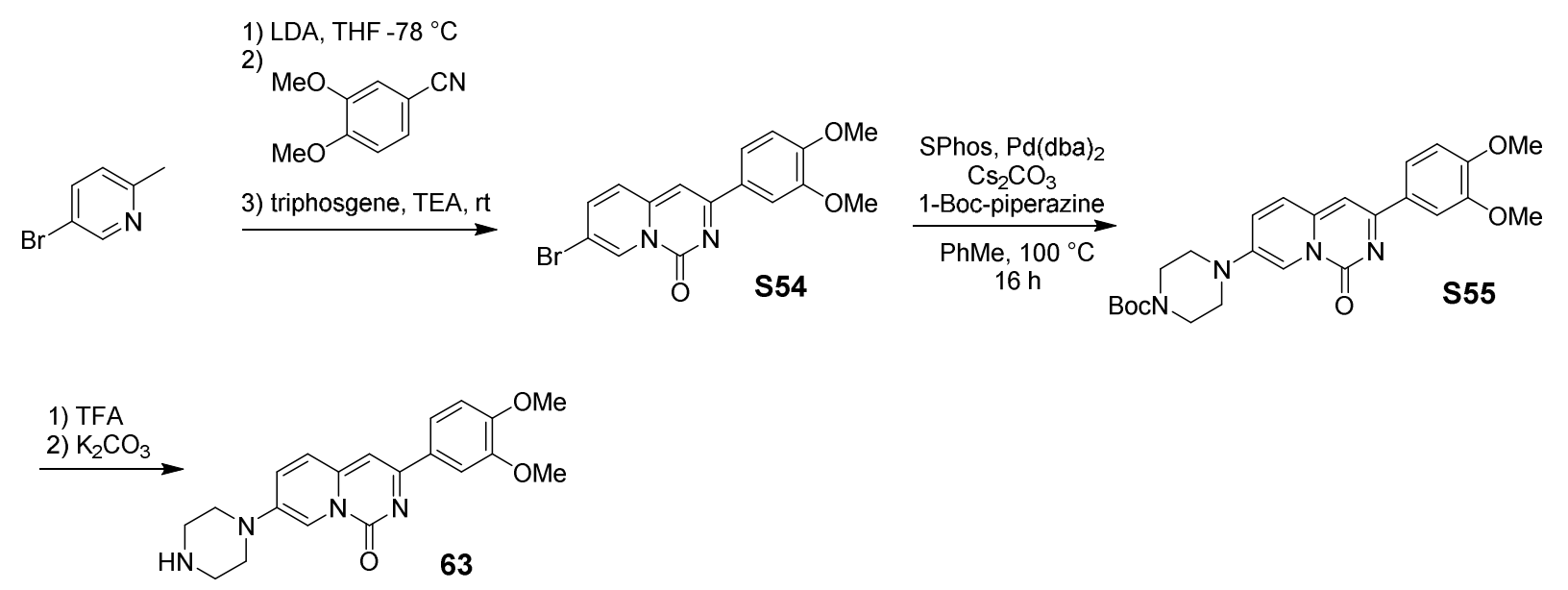

7-Bromo-3-(3,4-dimethoxyphenyl)-1H-pyrido[1,2-c]pyrimidin-1-one (S54). A solution of 2-methyl-5-bromopyridine ( $344 \mathrm{mg}, 2 \mathrm{mmol})$ in THF $(10 \mathrm{~mL})$ was cooled to $0{ }^{\circ} \mathrm{C}$. To the solution was added a $1.5 \mathrm{M}$ solution of lithium diisopropylamide in cyclohexane $(1.33 \mathrm{~mL}, 2$ $\mathrm{mmol}$ ). After $30 \mathrm{~min}$, a solution of 3,4-dimethoxybenzonitrile ( $326 \mathrm{mg}, 2 \mathrm{mmol}$ ) in THF ( $2 \mathrm{~mL}$ ) was added to the mixture. The mixture was allowed to warm to rt over $15 \mathrm{~min}$. After the mixture had stirred for $30 \mathrm{~min}$ at $\mathrm{rt}$, triphosgene $(794 \mathrm{mg}, 2 \mathrm{mmol}$ ) was added to the mixture, followed by the addition of triethylamine $(0.55 \mathrm{~mL}, 4 \mathrm{mmol})$. The mixture was stirred at $\mathrm{rt}$ for $30 \mathrm{~min}$, and was then partitioned between EtOAc $(100 \mathrm{~mL})$ and aqueous saturated $\mathrm{NaHCO}_{3}(50 \mathrm{~mL})$. The organic layer was dried over $\mathrm{Na}_{2} \mathrm{SO}_{4}$, filtered, concentrated and chromatographed on silica gel (0-10\% $\mathrm{MeOH}$ in $\mathrm{CH}_{2} \mathrm{Cl}_{2}$ ) to yield $\mathbf{S 5 4}(120 \mathrm{mg}, 33 \%)$. LC-MS: $\mathrm{m} / z=361.1,363.1[\mathrm{M}+\mathrm{H}]^{+}$.

tert-Butyl 4-(3-(3,4-dimethoxyphenyl)-1-oxo-1H-pyrido[1,2-c]pyrimidin-7yl)piperazine-1-carboxylate (S55). A mixture of $\mathbf{S 5 4}(120 \mathrm{mg}, 0.33 \mathrm{mmol}), 1$-bocpiperazine (123 mg, $0.66 \mathrm{mmol}), \mathrm{Cs}_{2} \mathrm{CO}_{3}(214 \mathrm{mg}, 0.66 \mathrm{mmol})$, SPhos (12 mg, $\left.0.03 \mathrm{mmol}\right)$, bis(dibenzylideneacetone)palladium $(0)(17 \mathrm{mg}, 0.03 \mathrm{mmol})$ and toluene $(2 \mathrm{~mL})$ was stirred at $100{ }^{\circ} \mathrm{C}$ under $\mathrm{N}_{2}$ for $16 \mathrm{~h}$. The mixture was chromatographed on silica gel $(0-10 \% \mathrm{MeOH}$ in $\mathrm{CH}_{2} \mathrm{Cl}_{2}$ ) to yield $\mathbf{S 5 5}$ (50 mg, 32\%). LC-MS: $m / z=467.2[\mathrm{M}+\mathrm{H}]^{+}$.

\section{3-(3,4-Dimethoxyphenyl)-7-(piperazin-1-yl)-1H-pyrido[1,2-c]pyrimidin-1-one (63). Compound S55 $(50 \mathrm{mg}, 0.11 \mathrm{mmol})$ was dissolved in TFA $(1 \mathrm{~mL})$. After $10 \mathrm{~min}$, the volatiles were removed from the reaction mixture with a stream of $\mathrm{N}_{2}$. The residue was partitioned in $\mathrm{CH}_{2} \mathrm{Cl}_{2}(10 \mathrm{~mL})$ and aqueous $1 \mathrm{M} \mathrm{K}_{2} \mathrm{CO}_{3}(5 \mathrm{~mL})$. The organic layer was concentrated to yield $\mathbf{6 3}$ (44 mg, 100\%) LC-MS: $m / z=367.1[\mathrm{M}+\mathrm{H}]^{+} ;{ }^{1} \mathrm{H}$ NMR $\left(500 \mathrm{MHz}\right.$, DMSO- $\left.d_{6}\right) \delta 8.31(\mathrm{~d}, J=2.5$ $\mathrm{Hz}, 1 \mathrm{H}), 8.03$ (dd, $J=9.6,2.3 \mathrm{~Hz}, 1 \mathrm{H}), 7.77-7.72(3 \mathrm{H}), 7.45(\mathrm{~s}, 1 \mathrm{H}), 7.09$ (d, $J=9.1 \mathrm{~Hz}, 1 \mathrm{H})$, $3.87(\mathrm{~s}, 3 \mathrm{H}), 3.84(\mathrm{~s}, 3 \mathrm{H}), 3.15(\mathrm{~m}, 4 \mathrm{H}), 2.88(\mathrm{~m}, 4 \mathrm{H})$.}

Scheme 22 


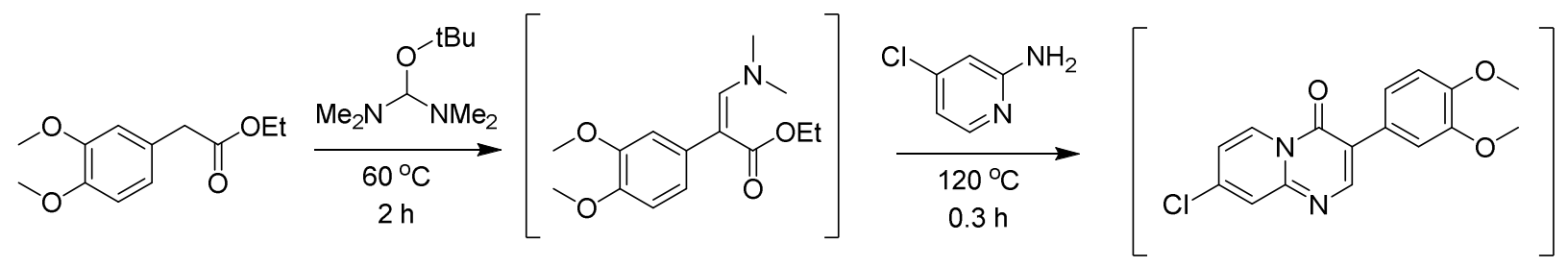<smiles>COc1ccc(-c2cnc3cc(N4CCNCC4)ccn3c2=O)cc1O</smiles>

3-(3,4-Dimethoxyphenyl)-8-(piperazin-1-yl)-4H-pyrido[1,2-a]pyrimidin-4-one (64). Ethyl 2-(3,4-dimethoxyphenyl)acetate $(673 \mathrm{mg}, 3 \mathrm{mmol})$ was combined with 1-tert-butoxy$\mathrm{N}, \mathrm{N}, \mathrm{N}^{\prime}, \mathrm{N}$-tetramethylmethanediamine $(0.68 \mathrm{~mL}, 3.3 \mathrm{mmol})$. The mixture was heated to $60{ }^{\circ} \mathrm{C}$ for $2 \mathrm{~h}$. To the mixture was added 4-chloropyridin-2-amine (424 mg, $3.3 \mathrm{mmol}$ ). The mixture was heated at $120^{\circ} \mathrm{C}$ for $20 \mathrm{~min}$. Piperazine $(1.3 \mathrm{~g}, 15 \mathrm{mmol})$ was added to the mixture and the mixture was stirred at $120{ }^{\circ} \mathrm{C}$ for an additional $30 \mathrm{~min}$. The mixture was chromatographed on silica gel $\left(10 \% \mathrm{MeOH}\right.$ w/ 1\% triethylamine in $\left.\mathrm{CH}_{2} \mathrm{Cl}_{2}\right)$ affording $64(120 \mathrm{mg}, 11 \%)$ as a yellow powder: $m p$ 175-179 ${ }^{\circ} \mathrm{C}$; LC-MS: $m / z=367.2[\mathrm{M}+\mathrm{H}]^{+} ;{ }^{1} \mathrm{H}$ NMR $\left(500 \mathrm{MHz}, \mathrm{DMSO}-d_{6}\right) \delta 8.85$ $(\mathrm{d}, J=8.82 \mathrm{~Hz}, 1 \mathrm{H}), 8.41(\mathrm{~s}, 1 \mathrm{H}), 7.45(\mathrm{~d}, J=1.9 \mathrm{~Hz}, 1 \mathrm{H}), 7.34(\mathrm{dd}, J=8.4,2.1 \mathrm{~Hz}, 1 \mathrm{H}), 7.29$ $(\mathrm{dd}, J=8.2,2.9 \mathrm{~Hz}, 1 \mathrm{H}), 6.99(\mathrm{~d}, J=8.8 \mathrm{~Hz}, 1 \mathrm{H}), 6.73(\mathrm{~d}, J=2.8 \mathrm{~Hz}, 1 \mathrm{H}), 3.80(\mathrm{~s}, 3 \mathrm{H}), 3.78$ (s, $3 \mathrm{H}), 3.48(\mathrm{~m}, 4 \mathrm{H}), 2.82(\mathrm{~m}, 4 \mathrm{H})$.

Scheme 23
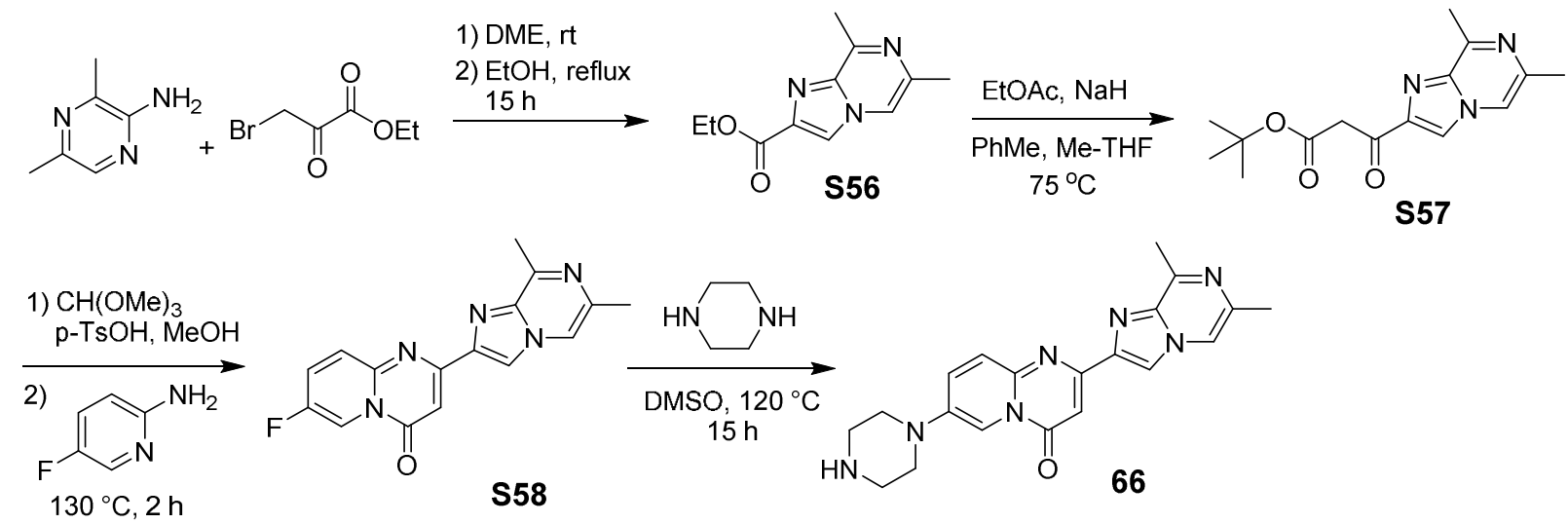

Ethyl 6,8-dimethylimidazo[1,2-a]pyrazine-2-carboxylate (S56). To a solution of 2amino-3,5-dimethylpyrazine (1.23 g, $10 \mathrm{mmol})$ in DME (10 mL) was added ethyl 3-bromo-2oxopropanoate $(1.57 \mathrm{~mL}, 12.5 \mathrm{mmol})$. The mixture was stirred at $\mathrm{rt}$ for $45 \mathrm{~min}$ and then filtered. The collected material was washed with $\mathrm{Et}_{2} \mathrm{O}$ and dried to give a yellow solid. The solid was suspended in EtOH $(15 \mathrm{~mL})$ and heated at $90^{\circ} \mathrm{C}$ for $3 \mathrm{~h}$. The mixture was partitioned between aqueous saturated $\mathrm{NaHCO}_{3}$ and EtOAc. The organic layer was dried over $\mathrm{NaSO}_{4}$, filtered and concentrated to give S56 (1.83 g, 83\%) as a light brown solid. LC-MS: $m / z=220.6[\mathrm{M}+\mathrm{H}]^{+}$. 
tert-Butyl 3-(6,8-dimethylimidazo[1,2-a]pyrazin-2-yl)-3-oxopropanoate (S57). To a solution of tert-butyl acetate $(1.08 \mathrm{~mL}, 8.0 \mathrm{mmol})$ in $\mathrm{THF}(40 \mathrm{~mL})$ at $-78{ }^{\circ} \mathrm{C}$ was added a solution of lithium diisopropylamide in THF $(1.5 \mathrm{M}, 6.4 \mathrm{~mL}, 9.6 \mathrm{mmol})$. The mixture stirred at $-78^{\circ} \mathrm{C}$ for $30 \mathrm{~min}$, and then was cannulated into a solution of $\mathbf{S 5 6}(0.876 \mathrm{~g}, 4.0 \mathrm{mmol})$ in THF $(12 \mathrm{~mL})$ at $-50{ }^{\circ} \mathrm{C}$. The mixture stirred at $-50^{\circ} \mathrm{C}$ for $1.5 \mathrm{~h}$. Excess reagent was quenched with aqueous saturated $\mathrm{NH}_{4} \mathrm{Cl}$. After warming to rt, the mixture was extracted with EtOAc. The combined organic layers were washed with water and brine, dried over $\mathrm{Na}_{2} \mathrm{SO}_{4}$, filtered, and concentrated to give $\mathbf{S 5 7}(1.16 \mathrm{~g}, 89 \%)$ as a light yellow oil. LC-MS: $\mathrm{m} / z=290.0[\mathrm{M}+\mathrm{H}]^{+}$.

\section{2-(6,8-Dimethylimidazo[1,2-a]pyrazin-2-yl)-7-fluoro-4H-pyrido[1,2-a]pyrimidin-4-} one (S58). A mixture of $\mathbf{S 5 7}(580 \mathrm{mg}, 2 \mathrm{mmol}$ ), p-toluenesulfonic acid monohydrate (38 $\mathrm{mg}$, $0.2 \mathrm{mmol})$ and trimethylorthoformate $(0.44 \mathrm{~mL}, 4 \mathrm{mmol})$ in $\mathrm{MeOH}(5 \mathrm{~mL})$ was heated at $65^{\circ} \mathrm{C}$ for $1 \mathrm{~h}$, and then concentrated. 2-Amino-5-fluoropyridine $(0.27 \mathrm{~g}, 2.4 \mathrm{mmol})$ was added to the mixture which was then heated at $150{ }^{\circ} \mathrm{C}$ for $1 \mathrm{~h}$, cooled, and then chromatographed on silica gel $\left(0-5 \% \mathrm{MeOH}\right.$ in $\left.\mathrm{CH}_{2} \mathrm{Cl}_{2}\right)$ to give $\mathbf{S 5 8}(124 \mathrm{mg}, 20 \%)$ as a yellow solid. LC-MS: $m / z=310.0$ $[\mathrm{M}+\mathrm{H}]^{+}$.

\section{2-(6,8-Dimethylimidazo[1,2-a]pyrazin-2-yl)-7-(piperazin-1-yl)-4H-pyrido[1,2-}

a]pyrimidin-4-one (66). A mixture of $\mathbf{S 5 8}(62 \mathrm{mg}, 0.2 \mathrm{mmol})$ and piperazine $(86 \mathrm{mg}, 1.0$ mmol) in DMSO $(0.5 \mathrm{~mL})$ was heated at $120^{\circ} \mathrm{C}$ for $1.5 \mathrm{~h}$. The dark brown mixture was chromatographed on silica gel $\left(0-10 \% \mathrm{MeOH}\right.$ in $\left.\mathrm{CH}_{2} \mathrm{Cl}_{2}\right)$ to give $\mathbf{6 6}(46 \mathrm{mg}, 61 \%)$ as a yellow solid. LC-MS: $m / z=376.5[\mathrm{M}+\mathrm{H}]^{+} .^{1} \mathrm{H}$ NMR $\left(500 \mathrm{MHz}, \mathrm{DMSO}-d_{6}\right) \delta 8.58(\mathrm{~s}, 1 \mathrm{H}), 8.32(\mathrm{br} \mathrm{s}$, $2 \mathrm{H}), 8.09(\mathrm{~m}, 1 \mathrm{H}), 7.72(\mathrm{~d}, J=9.8 \mathrm{~Hz}, 1 \mathrm{H}), 7.04(\mathrm{~s}, 1 \mathrm{H}), 3.39(\mathrm{br} \mathrm{s}, 4 \mathrm{H}), 3.21(\mathrm{br} \mathrm{s}, 4 \mathrm{H}), 2.77$ (s, $3 \mathrm{H}), 2.40(\mathrm{~s}, 3 \mathrm{H})$.

Scheme 24, Part A

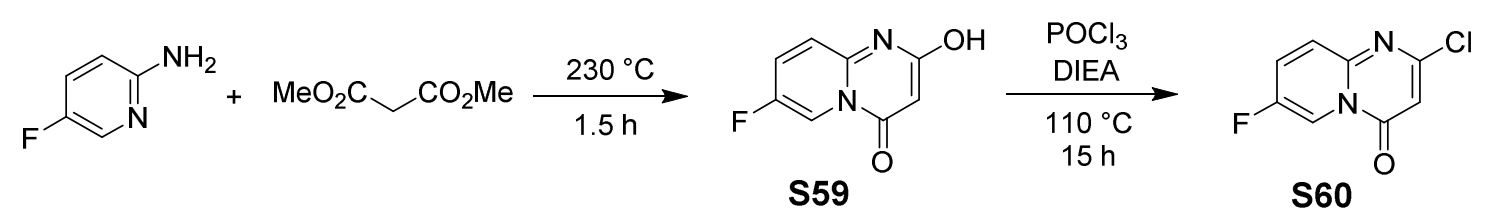

7-Fluoro-2-hydroxy-4H-pyrido[1,2-a]pyrimidin-4-one (S59). A mixture of 2-amino-5fluoropyridine $(11.20 \mathrm{~g}, 0.10 \mathrm{~mol})$ and dimethyl malonate $(57.0 \mathrm{~mL}, 0.50 \mathrm{~mol})$ was heated at 230 ${ }^{\circ} \mathrm{C}$ for $1.5 \mathrm{~h}$. After cooling the mixture to $\mathrm{rt}$, the solid material was removed by filtration and washed with $\mathrm{CH}_{3} \mathrm{CN}(3 \mathrm{X})$ to give $\mathbf{S 5 9}(14.0 \mathrm{~g}, 78 \%)$ as a dark solid. LC-MS: $m / z=181.3$ $[\mathrm{M}+\mathrm{H}]^{+}$.

2-Chloro-7-fluoro-4H-pyrido[1,2-a]pyrimidin-4-one (S60). A dark mixture of crude $\mathbf{S 5 9}$ $(14 \mathrm{~g}, \sim 77 \mathrm{mmol}), \mathrm{POCl}_{3}(50 \mathrm{~mL})$ and DIEA $(13.3 \mathrm{~mL}, 77 \mathrm{mmol})$ was heated at $110^{\circ} \mathrm{C}$ for $15 \mathrm{~h}$. The volatiles were removed from the mixture. The dark solid residue was treated with ice-water, collected by filtration, washed with water (3X) and dried. The solid was chromatographed on silica gel (5\% $\mathrm{MeOH}$ in $\mathrm{CH}_{2} \mathrm{Cl}_{2}$ ) to give $\mathbf{S 6 0}(9.84 \mathrm{~g}, 64 \%)$ as a yellow solid. $\mathrm{LC}-\mathrm{MS}: \mathrm{m} / z=$ 
199.2 $[\mathrm{M}+\mathrm{H}]^{+} ;{ }^{1} \mathrm{H}$ NMR (500 MHz, DMSO- $\left.d_{6}\right) \delta 8.99(\mathrm{dd}, J=4.7,2.8 \mathrm{~Hz}, 1 \mathrm{H}), 8.25(\mathrm{~m}, 1 \mathrm{H})$, $7.85(\mathrm{dd}, J=9.8,5.4 \mathrm{~Hz}, 1 \mathrm{H}), 6.56(\mathrm{~s}, 1 \mathrm{H})$.

Scheme 24, Part B
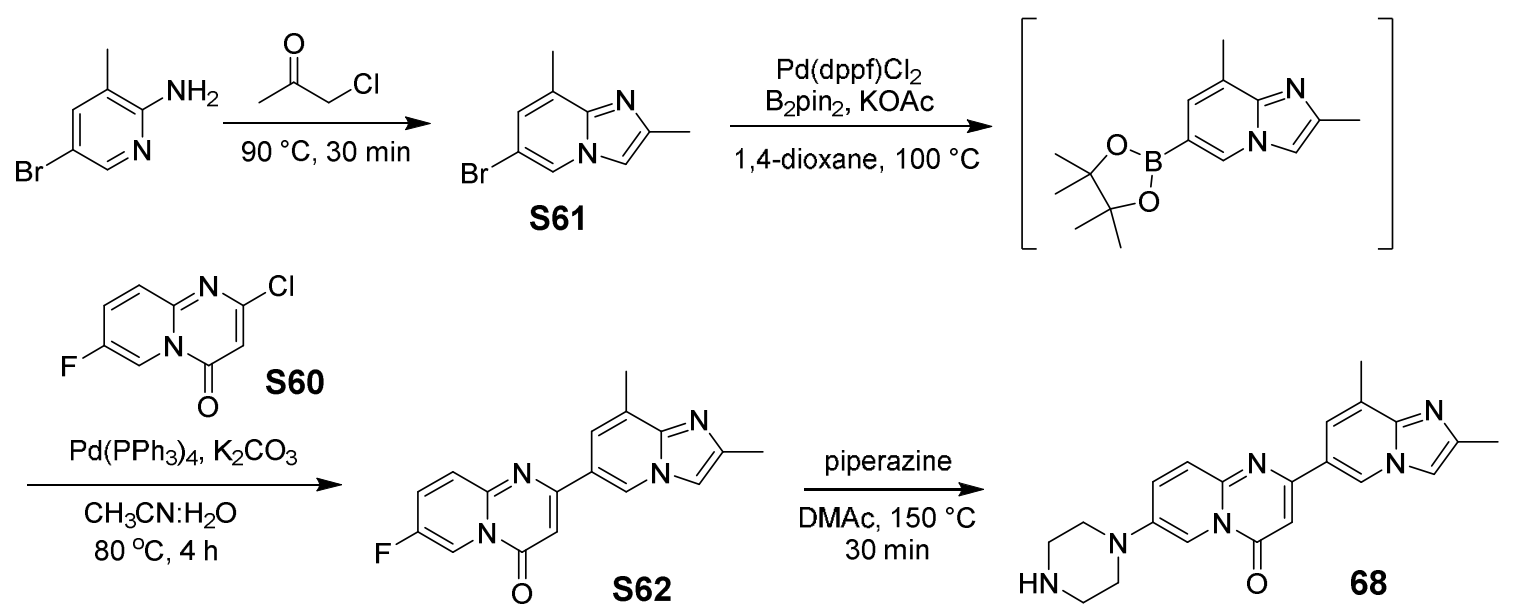

6-Bromo-8-methyl-2-methylimidazo[1,2-a]pyridine (S61). 5-Bromo-3-methylpyridin-2amine $(935 \mathrm{mg}, 5 \mathrm{mmol})$ was combined with chloroacetone $(0.44 \mathrm{~mL}, 5.5 \mathrm{mmol})$. The mixture was stirred at $90{ }^{\circ} \mathrm{C}$ for $30 \mathrm{~min}$. The mixture was partitioned between $\mathrm{CH}_{2} \mathrm{Cl}_{2}(50 \mathrm{~mL})$ and aqueous saturated $\mathrm{NaHCO}_{3}(50 \mathrm{~mL})$. The organic layer was concentrated to yield $\mathbf{S 6 1}(340 \mathrm{mg}$, 30\%). LC-MS: $m / z=225.0,227.0[\mathrm{M}+\mathrm{H}]^{+}$.

\section{2-(2,8-Dimethylimidazo[1,2-a]pyridin-6-yl)-7-fluoro-4H-pyrido[1,2-a]pyrimidin-4-} one (S62). A mixture of S61 (340 mg, $1.5 \mathrm{mmol})$, KOAc (294 mg, $3 \mathrm{mmol}$ ), bis(pinacolato)diboron (457 mg, $1.8 \mathrm{mmol}$ ), [1,1'-bis(diphenylphosphino)ferrocene]dichloropalladium(II) dichlormethane complex (122 mg, $0.1 \mathrm{mmol})$ and 1,4-dioxane $(7.5 \mathrm{~mL})$ was stirred at $80{ }^{\circ} \mathrm{C}$ for $16 \mathrm{~h}$. To the mixture was added aqueous $1 \mathrm{M} \mathrm{K}_{2} \mathrm{CO}_{3}(3 \mathrm{~mL})$, $\mathbf{S 6 0}$ (300 $\mathrm{mg}, 1.5 \mathrm{mmol}$ ) and additional [1,1'-bis(diphenylphosphino)ferrocene]-dichloropalladium(II) dichlormethane complex $(122 \mathrm{mg}, 0.1 \mathrm{mmol})$. The mixture stirred at $80{ }^{\circ} \mathrm{C}$ for $16 \mathrm{~h}$. The mixture was partitioned between $\mathrm{CH}_{2} \mathrm{Cl}_{2}(50 \mathrm{~mL})$ and $\mathrm{H}_{2} \mathrm{O}(50 \mathrm{~mL})$. The organic layer was concentrated and chromatographed on silica gel $\left(0-10 \% \mathrm{MeOH}\right.$ in $\left.\mathrm{CH}_{2} \mathrm{Cl}_{2}\right)$ to yield $\mathbf{S 6 2}(230 \mathrm{mg}, 50 \%)$.

LC-MS: $m / z=309.0[\mathrm{M}+\mathrm{H}]^{+}$.

\section{2-(2,8-Dimethylimidazo[1,2-a]pyridin-6-yl)-7-(piperazin-1-yl)-4H-pyrido[1,2-}

a]pyrimidin-4-one (68). A mixture of $\mathbf{S 6 2}(230 \mathrm{mg}, 0.74 \mathrm{mmol})$, piperazine (318 $\mathrm{mg}, 3.7$ mmol) and $N, N$-dimethylacetamide $(0.5 \mathrm{~mL})$ was stirred at $150{ }^{\circ} \mathrm{C}$ for $30 \mathrm{~min}$. After cooling the mixture to rt, a precipitate formed. The solid was collected, washed with EtOH and dried to yield $68(100 \mathrm{mg}, 36 \%)$. LC-MS: $m / z=375.1[\mathrm{M}+\mathrm{H}]^{+} .{ }^{1} \mathrm{H}$ NMR $\left(500 \mathrm{MHz}, \mathrm{DMSO}-d_{6}\right) \delta 9.20(\mathrm{~d}, J=$ $1.0 \mathrm{~Hz}, 1 \mathrm{H}), 8.22(\mathrm{~d}, J=2.5 \mathrm{~Hz}, 1 \mathrm{H}), 8.09(\mathrm{dd}, J=9.8,2.8 \mathrm{~Hz}, 1 \mathrm{H}), 7.80-7.76(2 \mathrm{H}), 7.69(\mathrm{~d}, J=$ $9.8 \mathrm{~Hz}, 1 \mathrm{H}), 6.93(\mathrm{~s}, 1 \mathrm{H}), 3.17-3.13(4 \mathrm{H}), 2.91-2.87(4 \mathrm{H}), 2.53(\mathrm{~s}, 3 \mathrm{H}), 2.36(\mathrm{~s}, 3 \mathrm{H})$.

Scheme 25 

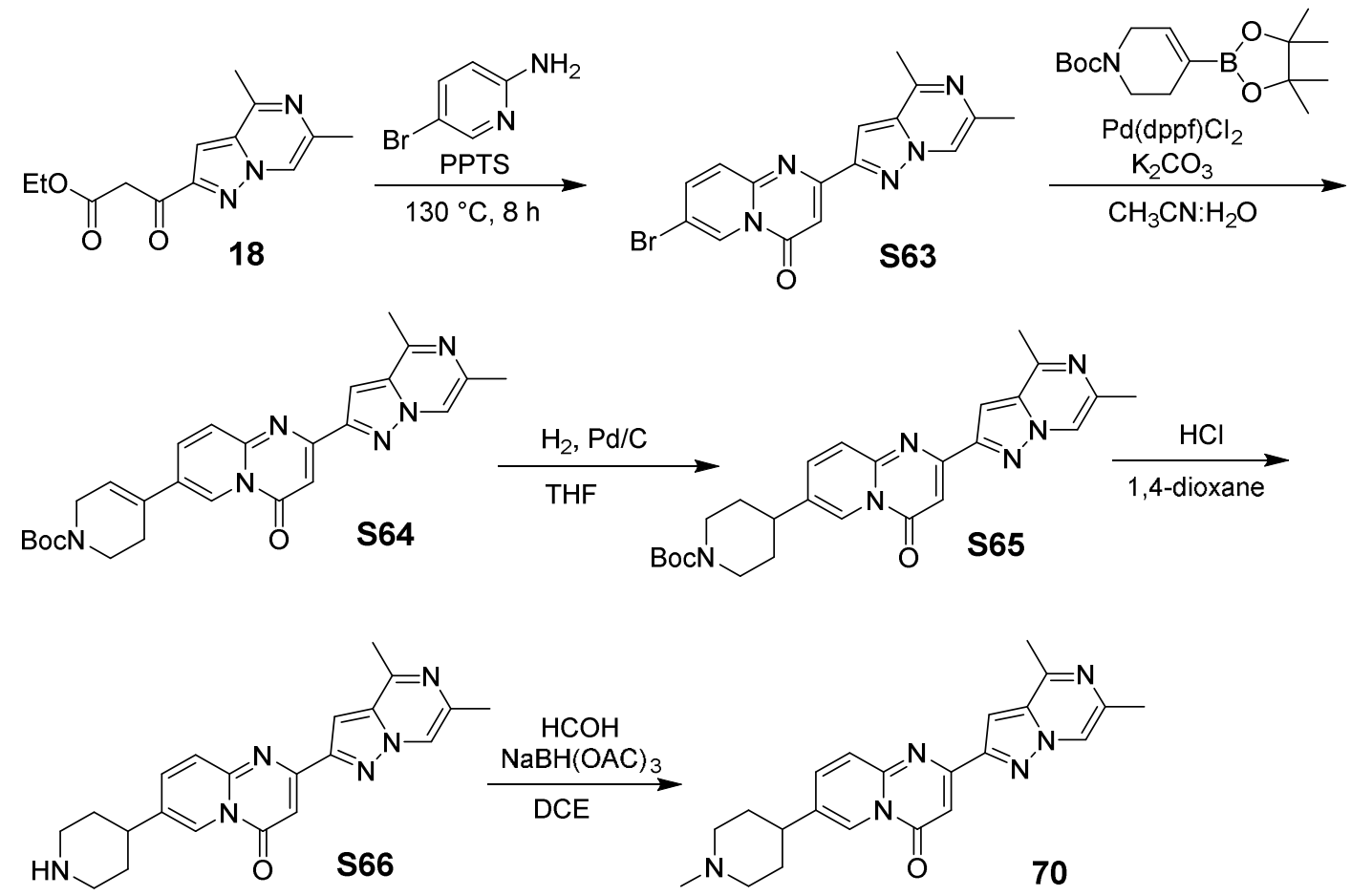

7-Bromo-2-(4,6-dimethylpyrazolo[1,5-a]pyrazin-2-yl)-4H-pyrido[1,2-a]pyrimidin-4one (S63). A mixture of 2-amino-5-bromopyridine (415 mg, $2.4 \mathrm{mmol}), 18$ (520 mg, $2.0 \mathrm{mmol}$ ) and pyridinium p-toluenesulfonate $(25 \mathrm{mg}, 0.1 \mathrm{mmol})$ was heated at $130{ }^{\circ} \mathrm{C}$ for $8 \mathrm{~h}$. The mixture was cooled to rt and chromatographed on silica gel (2-4\% $\mathrm{MeOH}$ in $\left.\mathrm{CH}_{2} \mathrm{Cl}_{2}\right)$ affording $\mathbf{S 6 3}$ (498 $\mathrm{mg}, 67 \%)$ as a yellow solid. LC-MS: $\mathrm{m} / \mathrm{z}=370.2,372.2[\mathrm{M}+\mathrm{H}]^{+} ;{ }^{1} \mathrm{H}$ NMR $(500 \mathrm{MHz}$, DMSO$\left.d_{6}\right) \delta 9.04(\mathrm{~m}, 1 \mathrm{H}), 8.57(\mathrm{~m}, 1 \mathrm{H}), 8.13(\mathrm{~m}, 1 \mathrm{H}), 7.71(\mathrm{~m}, 1 \mathrm{H}), 7.59(\mathrm{~m}, 1 \mathrm{H}), 7.05(\mathrm{~m}, 1 \mathrm{H}), 2.74$ (s, 3H), $2.44(\mathrm{~s}, 3 \mathrm{H})$.

tert-Butyl 4-(2-(4,6-dimethylpyrazolo[1,5-a]pyrazin-2-yl)-4-oxo-4H-pyrido[1,2a]pyrimidin-7-yl)-5,6-dihydropyridine-1(2H)-carboxylate (S64). A mixture of $\mathbf{S 6 3}$ (498 $\mathrm{mg}, 1.3 \mathrm{mmol}$ ), tert-butyl 4-(4,4,5,5-tetramethyl-1,3,2-dioxaborolan-2-yl)-5,6-dihydropyridine$1(2 \mathrm{H})$-carboxylate $(482 \mathrm{mg}, 1.56 \mathrm{mmol}), \mathrm{K}_{2} \mathrm{CO}_{3}(538 \mathrm{mg}, 3.9 \mathrm{mmol})$ and $\mathrm{Pd}(\mathrm{dppf}) \mathrm{Cl}_{2}(95 \mathrm{mg}$, $0.13 \mathrm{mmol})$ in $\mathrm{CH}_{3} \mathrm{CN}(3 \mathrm{~mL})$ was degassed and heated under $\mathrm{N}_{2}$ at $60{ }^{\circ} \mathrm{C}$ for $15 \mathrm{~h}$. The mixture was cooled to rt, concentrated and chromatographed on silica gel $\left(2-5 \% \mathrm{MeOH}\right.$ in $\left.\mathrm{CH}_{2} \mathrm{Cl}_{2}\right)$ to give S64 $(0.57 \mathrm{~g}, 84 \%)$ as an off-white solid. LC-MS: $m / z=473.5[\mathrm{M}+\mathrm{H}]^{+} ;{ }^{1} \mathrm{H}$ NMR $(500 \mathrm{MHz}$, DMSO- $\left.d_{6}\right) \delta 8.85(\mathrm{~m}, 1 \mathrm{H}), 8.57(\mathrm{~m}, 1 \mathrm{H}), 8.28(\mathrm{~m}, 1 \mathrm{H}), 7.75(\mathrm{~m}, 1 \mathrm{H}), 7.58(\mathrm{~m}, 1 \mathrm{H}), 7.02(\mathrm{~m}$, $1 \mathrm{H}), 6.66(\mathrm{br} \mathrm{s}, 1 \mathrm{H}), 4.08(\mathrm{~m}, 2 \mathrm{H}), 3.60(\mathrm{~m}, 2 \mathrm{H}), 2.74(\mathrm{~s}, 3 \mathrm{H}), 2.55(\mathrm{~m}, 2 \mathrm{H}), 2.43(\mathrm{~s}, 3 \mathrm{H}), 1.44(\mathrm{~s}$, $9 \mathrm{H})$.

\section{tert-Butyl 4-(2-(4,6-dimethylpyrazolo[1,5-a]pyrazin-2-yl)-4-oxo-4H-pyrido[1,2-} a]pyrimidin-7-yl)piperidine-1-carboxylate (S65). A mixture of $\mathbf{S 6 4}$ (300 mg, $0.63 \mathrm{mmol}$ ) and $10 \% \mathrm{Pd} / \mathrm{C}(60 \mathrm{mg})$ in THF $(30 \mathrm{~mL})$ was vigorously stirred under $\mathrm{H}_{2}(1 \mathrm{~atm})$ for $2 \mathrm{~d}$. The mixture was filtered through Celite. The filtrate was concentrated to give $\mathbf{S 6 5}$ in quantitative yield. LC-MS: $m / z=475.4[\mathrm{M}+\mathrm{H}]^{+}$. 


\section{2-(4,6-Dimethylpyrazolo[1,5-a]pyrazin-2-yl)-7-(piperidin-4-yl)-4H-pyrido[1,2-}

a]pyrimidin-4-one (S66). To a solution of $\mathbf{S 6 5}(0.63 \mathrm{mmol})$ in $\mathrm{CH}_{2} \mathrm{Cl}_{2}(2 \mathrm{~mL})$ was added a solution of $4 \mathrm{~N} \mathrm{HCl}$ in 1,4-dioxane $(2 \mathrm{~mL})$. After $1 \mathrm{~h}$, volatiles were removed. The residue was partitioned between $\mathrm{CH}_{2} \mathrm{Cl}_{2}$ and saturated aqueous $\mathrm{NaHCO}_{3}$. The organic layer was concentrated and chromatographed on silica gel $\left(10 \% 3.5 \mathrm{~N} \mathrm{NH}_{3}\right.$ in $\mathrm{MeOH}$ in $\left.\mathrm{CH}_{2} \mathrm{Cl}_{2}\right)$ to give $\mathbf{S 6 6}(50 \mathrm{mg}$, $21 \%$ ) as an off-white solid. LC-MS: $m / z=375.4[\mathrm{M}+\mathrm{H}]^{+} ;{ }^{1} \mathrm{H}$ NMR $\left(500 \mathrm{MHz}\right.$, DMSO- $\left.d_{6}\right) \delta$ $8.79(\mathrm{~m}, 1 \mathrm{H}), 8.58(\mathrm{~s}, 1 \mathrm{H}), 8.05(\mathrm{~m}, 1 \mathrm{H}), 7.78(\mathrm{~m}, 1 \mathrm{H}), 7.60(\mathrm{~s}, 1 \mathrm{H}), 7.02(\mathrm{~s}, 1 \mathrm{H}), 3.16-3.09$ $(2 \mathrm{H}), 2.90(\mathrm{~m}, 1 \mathrm{H}), 2.74(\mathrm{~s}, 3 \mathrm{H}), 2.78-2.68(2 \mathrm{H}), 2.43(\mathrm{~s}, 3 \mathrm{H}), 1.93-1.80(2 \mathrm{H}), 1.73-1.58(2 \mathrm{H})$.

\section{2-(4,6-Dimethylpyrazolo[1,5-a]pyrazin-2-yl)-7-(1-methylpiperidin-4-yl)-4H-} pyrido[1,2-a]pyrimidin-4-one (70). To a mixture of $\mathbf{S 6 6}(25 \mathrm{mg}, 0.067 \mathrm{mmol})$ and formaldehyde $(37 \%$ in water, $0.75 \mathrm{~mL})$ in 1,2-dichloroethane $(1 \mathrm{~mL})$ was added sodium triacetoxyborohydride ( $40 \mathrm{mg}, 0.20 \mathrm{mmol}$ ). The mixture was stirred at $\mathrm{rt}$ for $40 \mathrm{~min}$. Excess reagent was quenched with aqueous saturated $\mathrm{NaHCO}_{3}$. The mixture was filtered and concentrated. The residue was chromatographed on silica gel $\left(0-5 \% \mathrm{MeOH}\right.$ in $\left.\mathrm{CH}_{2} \mathrm{Cl}_{2}\right)$ to give 70 (24 mg, 92\%) as an off-white solid. LC-MS: $\mathrm{m} / z=389.4[\mathrm{M}+\mathrm{H}]]^{+} ;{ }^{1} \mathrm{H}$ NMR $(500 \mathrm{MHz}$, DMSO- $\left.d_{6}\right) \delta 8.81(\mathrm{~m}, 1 \mathrm{H}), 8.57(\mathrm{~m}, 1 \mathrm{H}), 8.06(\mathrm{~m}, 1 \mathrm{H}), 7.78(\mathrm{~m}, 1 \mathrm{H}), 7.59(\mathrm{~m}, 1 \mathrm{H}), 7.02(\mathrm{~m}$, $1 \mathrm{H}), 2.93(\mathrm{~m}, 2 \mathrm{H}), 2.74$ (s, 3H), $2.73(\mathrm{~m}, 1 \mathrm{H}), 2.44$ (s, 3H), 2.25 (br s, 3H), 2.10-1.99 (2H), 1.91$1.82(2 \mathrm{H}), 1.79-1.66(2 \mathrm{H})$.

Scheme 26

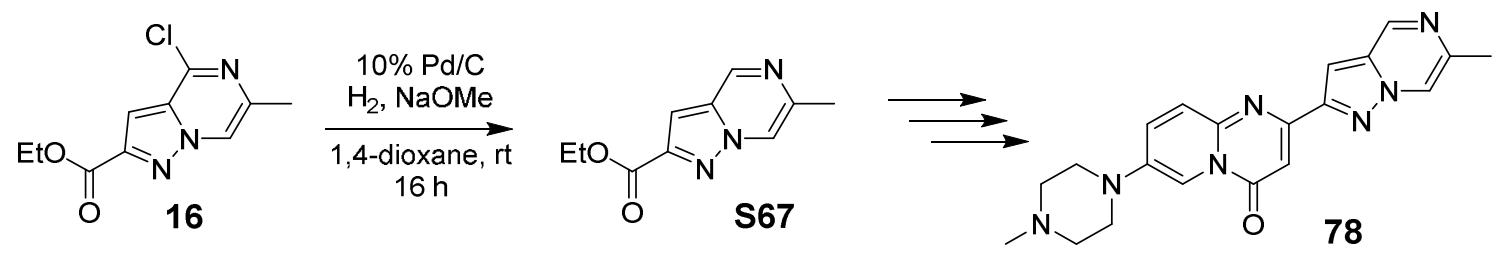

7-(4-Methylpiperazin-1-yl)-2-(6-methylpyrazolo[1,5-a]pyrazin-2-yl)-4H-pyrido[1,2a]pyrimidin-4-one (78). A mixture of $\mathbf{1 6}$ (3.97 g, $16.5 \mathrm{mmol})$, NaOMe (1.07 g, $19.8 \mathrm{mmol})$, and $10 \% \mathrm{Pd} / \mathrm{C}(1 \mathrm{~g})$ was stirred in 1,4-dioxane under $\mathrm{H}_{2}(1 \mathrm{~atm})$ at $\mathrm{rt}$ for $16 \mathrm{~h}$. The mixture was filtered over Celite. The filtrate was concentrated and chromatographed on silica gel (3\% EtOAc in $\mathrm{CH}_{2} \mathrm{Cl}_{2}$ ) to give $\mathbf{S 6 7}(1.3 \mathrm{~g}, 39 \%) .{ }^{1} \mathrm{H}$ NMR (DMSO- $\left.d_{6}\right) \delta 9.22(\mathrm{~d}, J=1.3 \mathrm{~Hz}, 1 \mathrm{H}), 8.74(\mathrm{~d}, J$ $=1.3 \mathrm{~Hz}, 1 \mathrm{H}), 7.42(\mathrm{~d}, J=0.9 \mathrm{~Hz}, 1 \mathrm{H}), 4.37$ (q, $J=7.0 \mathrm{~Hz}, 2 \mathrm{H}), 2.49(\mathrm{~s}, 3 \mathrm{H}), 1.35(\mathrm{t}, J=7.1 \mathrm{~Hz}$, $3 \mathrm{H})$. Compound $\mathbf{S 6 7}$ was treated similarly to compound $\mathbf{1 7}$ as described in Scheme 4 to give $\mathbf{7 8 .}$ ${ }^{1} \mathrm{H}$ NMR $\left(500 \mathrm{MHz}\right.$, DMSO- $\left.d_{6}\right) \delta 9.19(\mathrm{~s}, 1 \mathrm{H}), 8.74(\mathrm{~s}, 1 \mathrm{H}), 8.28(\mathrm{~d}, J=2.5 \mathrm{~Hz}, 1 \mathrm{H}), 8.13$ (dd, $J$ $=9.7,2.5 \mathrm{~Hz}, 1 \mathrm{H}), 7.75(\mathrm{~d}, J=9.6 \mathrm{~Hz}, 1 \mathrm{H}), 7.52(\mathrm{~s}, 1 \mathrm{H}), 6.97(\mathrm{~s}, 1 \mathrm{H}), 3.35(\mathrm{~m}, 4 \mathrm{H}), 3.25(\mathrm{~m}$, $4 \mathrm{H}), 2.48(\mathrm{~s}, 3 \mathrm{H}), 2.25$ (s, 3H). 


\section{Supplemental Table 1:}

\begin{tabular}{|ll|}
\hline Primer/Probe & Sequence \\
\hline SMN2 Forward Primer A & GAAGGAAGGTGCTCACATT \\
SMN2 Reverse Primer A & TCTTTATGTTTTTGGCGTCTTC \\
SMN2 Forward Probe A & 6FAM-AAGGAGAAATGCTGGCATAGAGCAGC-TAMRA \\
$h G A P D H$ Forward Probe & VIC-CGCCTGGTCACCAGGGCTGCT-TAMRA \\
$h G A P D H$ Forward Primer & CAACGGATTTGGTCGTATTGG \\
$h G A P D H$ Reverse Primer & TGATGGCAACAATATCCACTTTACC \\
\hline
\end{tabular}

